\title{
Diversity of copepods in Atlantic Patagonian coastal waters throughout an annual cycle
}

\section{Diversidad de copépodos en aguas costeras de la Patagonia en el Atlántico a lo largo de un ciclo anual}

\author{
Mariela L Spinelli1 ${ }^{1,2 *}$, Rodrigo J Gonçalves ${ }^{3,4}$, Virginia E Villafañe ${ }^{3,4}$, Fabiana L Capitanio ${ }^{1,2}$ \\ ${ }^{1}$ Laboratorio de Zooplancton Marino, Departamento de Biodiversidad y Biología Experimental, Facultad de \\ Ciencias Exactas y Naturales, Universidad de Buenos Aires, Argentina. \\ 2 Instituto de Biodiversidad y Biología Experimental y Aplicada, Consejo Nacional de Investigaciones \\ Científicas y Técnicas, Universidad de Buenos Aires, Intendente Güiraldes 2160, Pabellón 2, 4to. piso, \\ Ciudad Universitaria, C1428EGA, Buenos Aires, Argentina. \\ ${ }^{3}$ Consejo Nacional de Investigación Científicas y Técnicas (CONICET), Argentina. \\ ${ }^{4}$ Estación de Fotobiología Playa Unión, Juan Manuel de Rosas y Martín Rivadavia, Playa Unión, Rawson, \\ Chubut, Argentina. Casilla de correos 15 (9103).
}

* Corresponding author. E-mail: marielaspinelli@bg.fcen.uba.ar

\begin{abstract}
The aim of this study is to analyze the annual zooplankton succession at a coastal station in Patagonia (Argentina), with special emphasis on copepods and their potential preys, using solar radiation and temperature as environmental factors. The annual plankton cycle exhibited autumn/winter and spring/summer phases. During the autumn/winter phase, low temperature and radiation were correlated with higher diatom abundance and copepod diversity. This period was characterized by a dominant classical herbivorous food web in which the large copepod Calanoides carinatus dominated the community. On the contrary, during the spring/summer period, with high radiation and temperature levels, flagellates were the dominant food available for zooplankton and correlated with smaller species of copepods such as the harpacticoid Euterpina acutifrons. Also, intensive reproduction of the small copepods E. acutifrons and Paracalanus parvus occurred mainly in summer. On the other hand, high species diversity was found in winter when the ultraviolet radiation was low. The temporal pattern of the copepods observed in our study was explained by food availability and environmental factors (temperature and solar radiation), although other factors such as predator abundance may also be important in modulating the community. Our results show the importance of copepod abundance dynamics and highlights their key role in the pelagic food web in northern Patagonian coastal waters.
\end{abstract}

Key words: zooplankton, harpacticoid copepods, Argentinean Sea, phytoplankton.

RESUMEN. El objetivo de este estudio es analizar la sucesión anual del zooplancton en una estación costera en la Patagonia (Argentina), con especial énfasis en copépodos y sus posibles presas, en relación con la radiación solar y la temperatura como factores ambientales. El ciclo anual del plancton mostró dos periodos, otoño/invierno y primavera/verano. Durante el periodo otoño/invierno, la baja temperatura y la radiación se correlacionaron con la mayor abundancia de diatomeas y la mayor diversidad de copépodos. Este periodo se caracterizó por la dominancia de la cadena clásica herbívora, y el copépodo grande Calanoides carinatus dominó la comunidad. Por el contrario, durante el periodo de primavera/verano, con alta radiación y mayores niveles de temperatura, los flagelados fueron el alimento disponible para el zooplancton y se correlacionaron con las especies pequeñas de copépodos como el harpacticoideo Euterpina acutifrons. Además, la reproducción intensiva de los copépodos pequeños E. acutifrons y Paracalanus parvus se llevó a cabo principalmente en verano. Por otro lado, se encontró una alta diversidad de especies en invierno, cuando la radiación ultravioleta fue baja. El patrón temporal de los copépodos observado en nuestro estudio fue explicado por la disponibilidad de alimento y los factores ambientales (temperatura y radiación solar), aunque otros factores tales como la abundancia de los depredadores pueden ser también importantes en la modulación de la comunidad. Nuestros resultados muestran la importancia de la dinámica de la abundancia de copépodos y destaca su papel clave en las cadenas tróficas pelágicas de las aguas costeras de la Patagonia norte.

Palabras clave: zooplancton, copépodos harpacticoideos, mar Argentino, fitoplancton.

\section{INTRODUCTION}

Studies on seasonal cycles of zooplankton (e.g., Loots et al. 2009, Eloire et al. 2010, Grigor et al. 2014) provide critical information about the dynamics of the ecosystem, such as changes in biomass, size structure, species composition,

\section{INTRODUCCIÓN}

Los estudios sobre los ciclos estacionales de zooplancton (e.g., Loots et al. 2009, Eloire et al. 2010, Grigor et al. 2014) proporcionan información crítica acerca de la dinámica del ecosistema, como cambios en la biomasa, la estructura de 
distribution, growth, and reproduction (e.g., Mackas and Beaugrand 2010, Overland et al. 2010). They also address key questions such as the effects of climate change on plankton communities (Drinkwater et al. 2010, Perry et al. 2010). The demographic characteristics of marine mesozooplankton make them especially suitable for examining the variability of marine ecosystems (Mackas and Beaugrand 2010). This is particularly relevant in coastal areas, typically of considerable ecological, economic, and social importance (Calbet et al. 2001). In particular, polar and temperate seas are characterized by pronounced seasonal fluctuations in irradiance, temperature, phytoplankton abundance, and species composition, all factors that directly or indirectly influence the growth rate and production of copepods (Kiørboe and Nielsen 1994, Madsen et al. 2001).

Physical factors such as salinity and temperature also regulate the seasonal plankton succession. Solar radiation, in particular ultraviolet radiation (UVR, 280-400 nm), has overall negative effects on many aquatic organisms including zooplankton (Bancroft et al. 2007). UVR is known to affect both behavior and mortality rates in zooplankton communities (Gonçalves and Hylander 2014) and these in turn structure trophic interactions (Williamson et al. 2001, Gonçalves et al. 2010). Many copepod species are known to be susceptible to UVR exposure, which is reflected in suppressed reproduction and increased adult and juvenile mortality (Zagarese et al. 1994), among other effects.

In spite of the economic importance of Patagonian waters as nursery sites for Merluccius hubbsi, Engraulis anchoita, and Pleoticus muelleri (Hansen et al. 2001, Pájaro et al. 2004, De Carli et al. 2012), the area is still rather unexplored in terms of the annual cycles of plankton communities. Thus, there is an obvious need to understand the temporal and spatial dynamics of lower trophic levels that may help to explain the abundance and distribution of such important commercial species. Although the annual cycles of phytoplankton have been extensively reported (e.g., Villafañe et al. 2004, Halac et al. 2011, Villafañe et al. 2013), there are no comparable studies on the seasonal cycles of small copepods or other zooplankton groups. The aim of this work is to provide data on the seasonal succession of copepod species (calanoids, cyclopoids, and harpacticoids) in relation to the different fractions of available food throughout the year and to the fluctuations of environmental variables.

\section{MATERIALS AND METHODS}

\section{Study area}

This study was conducted at Engaño Bay $\left(43^{\circ} 21^{\prime} \mathrm{S}\right.$, $65^{\circ} 01^{\prime} \mathrm{W}$ ), Chubut, Argentina (Fig. 1), from August 2010 to February 2012. The study site is located in close proximity to the Chubut River estuary. The estuary receives nutrients (from anthropogenic activities) as river runoff, resulting in relatively high phytoplankton biomass (Helbling et al. 1992, tallas, la composición de las especies, la distribución, el crecimiento y la reproducción (e.g., Mackas y Beaugrand 2010, Overland et al. 2010). También abordan cuestiones clave como los efectos del cambio climático en las comunidades de plancton (Drinkwater et al. 2010, Perry et al. 2010). Las características demográficas del mesozooplancton marino lo vuelven especialmente adecuado para examinar la variabilidad de los ecosistemas marinos (Mackas y Beaugrand 2010). Esto es particularmente relevante en las zonas costeras, por su gran importancia ecológica, económica y social (Calbet et al. 2001). En particular, los mares polares y templados se caracterizan por su pronunciada estacionalidad de la radiación, temperatura, y abundancia y composición de especies de fitoplancton, factores que influyen directa o indirectamente en la tasa de crecimiento y producción de copépodos (Kiørboe y Nielsen 1994, Madsen et al. 2001).

Los factores físicos tales como la salinidad y la temperatura también regulan la sucesión estacional del plancton; la radiación solar, en particular la radiación ultravioleta (RUV, 280-400 nm), tiene efectos negativos en muchos organismos acuáticos, incluyendo el zooplancton (Bancroft et al. 2007). Se sabe que la RUV afecta a las tasas de comportamiento y de mortalidad en las comunidades del zooplancton (Gonçalves y Hylander 2014), y éstas a su vez estructuran las interacciones tróficas (Williamson et al. 2001, Gonçalves et al. 2010). En particular, muchas especies de copépodos son conocidas por ser susceptibles de la exposición a la RUV, que se refleja en una baja reproducción y una mayor mortalidad de adultos y juveniles (Zagarese et al. 1994), entre otros efectos.

A pesar de la importancia económica de la Patagonia como zona de cría de Merluccius hubbsi, Engraulis anchoita y Pleoticus muelleri (Hansen et al. 2001, Pájaro et al. 2004, De Carli et al. 2012), el área está todavía poco explorada en cuanto a los ciclos anuales de las comunidades de plancton. Por lo tanto, hay una necesidad de entender la dinámica temporal y espacial de los niveles tróficos inferiores que pueden ayudar a explicar la abundancia y distribución de tales especies de importancia comercial. Aunque hay diversos trabajos sobre los ciclos anuales de fitoplancton (e.g., Villafañe et al. 2004, Halac et al. 2011, Villafañe et al. 2013), no existen estudios sobre los ciclos estacionales de copépodos pequeños u otros grupos del zooplancton. Por lo tanto, el objetivo de este trabajo es proporcionar datos sobre la sucesión estacional de las especies de copépodos (calanoideos, ciclopoideos y harpacticoideos) en relación con las diferentes fracciones de alimento disponible durante todo el año, y con las fluctuaciones de las variables ambientales.

\section{MATERIALES Y MÉTODOS}

\section{Área de estudio}

Este estudio se realizó en bahía Engaño $\left(43^{\circ} 21^{\prime} \mathrm{S}\right.$, $65^{\circ} 01^{\prime} \mathrm{W}$ ), Chubut, Argentina (Fig. 1), de agosto de 2010 a 


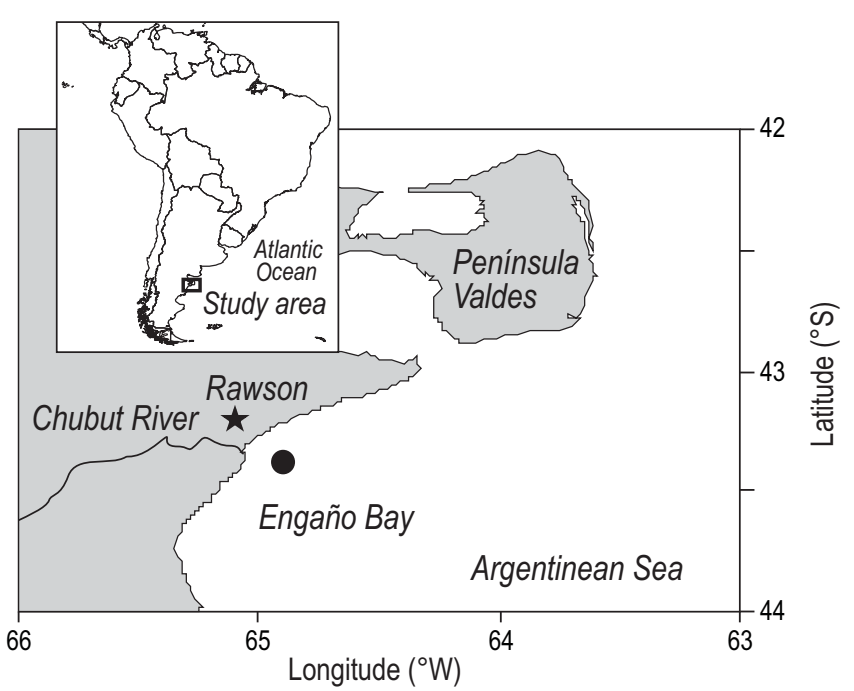

Figure 1. Map showing the study area in northern Patagonia, Argentina (SW Atlantic). The sampling site (black circle) was located at the mouth of the Chubut River estuary $\left(43^{\circ} 21^{\prime} \mathrm{S}\right.$, $\left.65^{\circ} 01^{\prime} \mathrm{W}\right)$.

Figura 1. Mapa que muestra el área de estudio en la costa norte de la Patagonia, Argentina. El sitio de muestreo (círculo negro) se encuentra en la desembocadura del estuario del Río Chubut $\left(43^{\circ} 21^{\prime} \mathrm{S}, 65^{\circ} 01^{\prime} \mathrm{W}\right)$.

2010). It has an important diversity of phytoplankton species (Villafañe et al. 2004, 2008) with a characteristic winter bloom (Barbieri et al. 2002, Villafañe et al. 2004). This microplankton bloom $(>20 \mu \mathrm{m})$ seems to be favored by the prevailing low wind conditions at this time of the year (Villafañe et al. 2004, Helbling et al. 2005), in contrast with the windy season (spring and summer) during which picoplanktonic and nanoplanktonic $(<20 \mu \mathrm{m})$ cells dominate in terms of abundance (Barbieri et al. 2002; Villafañe et al. 2004, 2008).

\section{Sample collection and analysis}

Zooplankton samples were taken every $\sim 30$ days in the outer part of the estuary ( $\sim 5 \mathrm{~km}$ offshore) by surface trawls (towing time: $2 \mathrm{~min}$; towing rate: $60 \mathrm{~m} \mathrm{~min}^{-1}$ ) with a plankton net (67 $\mu \mathrm{m}$ mesh size, $30 \mathrm{~cm}$ mouth opening diameter). The mesh size was chosen to optimize retention of both adults and immature stages of zooplankton (Di Mauro et al. 2009, Antacli et al. 2010). The trawls were done from a small pneumatic boat with careful observation of the operator. No clogging or reflux during trawling of the nets was observed. The volume of filtered water was estimated by means of a mechanical flowmeter (General Oceanics). The samples were preserved in 5\% formalin in seawater for abundance and species analysis. Zooplankton was quantified and the density (ind $\mathrm{m}^{-3}$ ) of each class/order was estimated from the volume of filtered seawater. The different taxa/groups were separated under a stereomicroscope (Zeiss 475052-9901) and those febrero de 2012. El sitio se localiza cerca de la desembocadura del río Chubut. El estuario recibe nutrientes (de actividades antropogénicas) por la corriente del río, lo que genera una alta biomasa de fitoplancton (Helbling et al. 1992, 2010). Tiene una gran diversidad de especies de fitoplancton (Villafañe et al. 2004, 2008) y se caracteriza por presentar una floración en invierno (Barbieri et al. 2002, Villafañe et al. 2004). Esta floración de microplancton $(>20 \mu \mathrm{m})$ parece estar favorecida por las condiciones de poco viento que prevalecen en esta época del año (Villafañe et al. 2004, Helbling et al. 2005), en contraste con la temporada de viento (primavera $\mathrm{y}$ verano) cuando el plancton de la fracción pico y nano $(<20 \mu \mathrm{m})$ domina en términos de abundancia (Barbieri et al. 2002; Villafañe et al. 2004, 2008).

\section{Recolección y análisis de las muestras}

Las muestras de zooplancton fueron tomadas cada $\sim 30$ días en la parte exterior del estuario $(\sim 5 \mathrm{~km}$ de la costa) realizando arrastres superficiales (tiempo de remolque: 2 min; velocidad: $60 \mathrm{~m} \mathrm{~min}^{-1}$ ) con una red de plancton (67 $\mu \mathrm{m}$ de luz de malla, $30 \mathrm{~cm}$ de diámetro de abertura). El tamaño de la malla fue elegida para optimizar la retención de los adultos y estados inmaduros del zooplancton (Di Mauro et al. 2009, Antacli et al. 2010). Los arrastres se realizaron desde una pequeña embarcación neumática con la observación cuidadosa del operador. No se observó obstrucción o reflujo durante el arrastre de la red. El volumen de agua filtrada se estimó por medio de un flujómetro mecánico (General Oceanics). Las muestras se conservaron en formalina al 5\% con agua de mar para la estimación y análisis de la abundancia. La densidad de zooplancton (ind $\mathrm{m}^{-3}$ ) se cuantificó para cada clase u orden a partir del volumen de agua de mar filtrada. Los diferentes taxones/grupos fueron separados bajo un microscopio estereoscópico (Zeiss 475052-9901) y las muestras con $>300$ individuos se fraccionaron en alícuotas de $20 \mathrm{~mL}$. Para los taxones menos abundantes, se analizó la muestra completa. Los copépodos fueron identificados a nivel de especie según Bradford-Grieve et al. (1999). Las etapas de desarrollo (nauplio, copepoditos I-III y IV-V) también se diferenciaron, y el largo del prosoma de 1,223 individuos de las tres especies dominantes se midió con un microscopio óptico (Olympus BHS) equipado con un micrómetro ocular. Los taxones restantes se identificaron a nivel de clase según Boltovskoy (1999).

Para la estimación de la abundancia y la identificación de fitoplancton, $50 \mathrm{~mL}$ de la muestra de agua fueron preservados con formalina neutralizada $(0.4 \%$ de concentración de formaldehído final en la muestra) y analizados usando la técnica de Utermöhl (1958), en un microscopio invertido (Leica DM IL). También se recolectaron muestras de agua para la determinación de la Chla. En el laboratorio, la concentración de Chla se determinó mediante el filtrado de $500 \mathrm{~mL}$ de agua recolectada en un filtro Whatman $\mathrm{GF} / \mathrm{F}$ $(25 \mathrm{~mm})$ y la extracción de los pigmentos fotosintéticos 
samples with $>300$ specimens were fractionated in $20-\mathrm{mL}$ aliquots. For the least abundant taxa, the entire sample was analyzed. Copepods were identified to the species level according to Bradford-Grieve et al. (1999). Developmental stages (nauplii, copepodites I-III and IV-V) were also differentiated, and the individual size (prosome length) of 1,223 individuals of the three dominant species was measured with an optical microscope (Olympus BHS) equipped with an ocular micrometer. The remaining taxa were identified to the class level according to Boltovskoy (1999).

Water samples $(50 \mathrm{~mL})$ for phytoplankton identification and abundance were preserved with buffered formaline ( $0.4 \%$ final formaldehyde concentration in the sample) and analyzed using the Utermöhl (1958) technique, under an inverted microscope (Leica DM IL). Water samples were also collected for the determination of chlorophyll $a$ (Chla). In the laboratory, Chla concentration was determined by filtering $500 \mathrm{~mL}$ of the collected water onto Whatman $\mathrm{GF} / \mathrm{F}$ filters $(25 \mathrm{~mm})$ and extracting photosynthetic pigments in absolute methanol (Holm-Hansen and Riemann 1978). Chla concentration was determined by fluorometric techniques using a fluorometer (TD-700, Turner Designs). Chla in the pico- and nanoplankton fraction $(2-20 \mu \mathrm{m})$ was estimated as the difference between total Chla and that of a pre-filtered $(20-\mu \mathrm{m}$ mesh) 500-mL aliquot.

Water temperature and salinity were registered using a multiparametric probe (YSI 600 XLM, Yellow Springs Instruments, Inc., USA). Solar UVR was continuously measured with a broadband radiometer (Eldonet, Real Time Computers, Inc., Germany), which measures ultraviolet B (UVB, 280-320 nm), ultraviolet A (UVA, 320-400 nm), and photosynthetically active radiation (PAR, 400-700 nm) with a frequency of one datum per minute.

\section{Data analysis}

Based on copepod abundance, ecological diversity indices were calculated to estimate changes in taxonomic composition. The Shannon-Weaver diversity index $\left(H^{\prime}\right)$ (Shannon and Weaver 1949) was used for the estimation of community diversity. Species richness was calculated with the Margalef index (d) (Margalef 1958), and the evenness of the samples was estimated using the Pielou index ( $\left.J^{\prime}\right)$ (Pielou 1969). Principal component analysis (PCA) was applied to evaluate the relationships among the abundance of each phytoplankton group (diatoms, flagellates, and dinoflagellates), the concentration of Chla (total and $<20 \mu \mathrm{m}$ ), the abundance of copepod species, the diversity indices $\left(H^{\prime}, d\right.$, and $\left.J^{\prime}\right)$, and abiotic variables (temperature and UVR [UVB + UVA] and PAR). A multivariate analysis of numerical classification was used to define sample groups with distinct copepod species composition (cluster). Prior to analysis, data were transformed using $\log (x+1)$. Hierarchical agglomerative clustering was carried out using the Bray-Curtis similarity index (Bray and Curtis 1957) coupled with group average. The sample groups en metanol absoluto (Holm-Hansen y Riemann 1978). La concentración de Chla se determinó mediante técnicas fluorométricas utilizando un fluorómetro (TD-700, Turner Designs). La fracción de Chla del pico y nanoplancton $(2-20 \mu \mathrm{m})$ se estimó mediante la diferencia entre la Chla total y aquella obtenida de la filtración (filtro de $20 \mu \mathrm{m}$ ) de una alícuota de $500 \mathrm{~mL}$ de agua.

La temperatura y la salinidad del agua se registraron utilizando una sonda multiparamétrica (YSI 600 XLM, Yellow Spring Instruments, Inc., EUA). La radiación solar ultravioleta se midió continuamente con un radiómetro de banda ancha (Eldonet, Real Time Computers, Inc., Alemania) que mide radiación ultravioleta $B$ (UVB, 280-320 nm), radiación ultravioleta A (UVA, 320-400 nm) y radiación fotosintéticamente activa (RFA, 400-700 nm) con una frecuencia de un dato por minuto.

\section{Análisis de los datos}

Se calcularon los índices de diversidad ecológica para estimar los cambios en la composición taxonómica de los copépodos. Se utilizó el índice de diversidad de ShannonWeaver $\left(H^{\prime}\right)$ (Shannon y Weaver 1949) para la estimación de la diversidad de la comunidad. La riqueza de especies se calculó con el índice de Margalef (d) (Margalef 1958), y se estimó la equitatividad de las muestras utilizando el índice de Pielou $\left(J^{\prime}\right)$ (Pielou 1969). Se aplicó el análisis de componentes principales (PCA, por sus siglas en inglés) para evaluar las relaciones entre la abundancia de cada grupo de fitoplancton (diatomeas, dinoflagelados y flagelados), la concentración de Chla (total $\mathrm{y}<20 \mu \mathrm{m}$ ), la abundancia de especies de copépodos, los índices de diversidad $\left(H^{\prime}, d\right.$ y $\left.J^{\prime}\right)$ y las variables abióticas (temperatura y RUV [UVB + UVA] y RFA). Se utilizó un análisis multivariado de clasificación numérica para definir grupos de acuerdo con la abundancia de las especies de copépodos (agrupación). Los datos se transformaron usando $\log (x+1)$. Se aplicó un análisis de conglomerados por el método jerárquico utilizando el índice de similitud de Bray-Curtis (Bray y Curtis 1957). Los grupos que resultaron del análisis de similitud (índice de distancia euclidea) de las variables ambientales seleccionadas se analizaron mediante un análisis de escalamiento multidimensional (MDS) no métrico. Para examinar la contribución de cada taxón a la similitud dentro de un grupo y disimilitud entre los grupos, se aplicó un análisis de porcentaje de similitud (SIMPER) utilizando el índice de similitud de Bray-Curtis. Los programas PRIMER 5.0 (Clarke y Warwick 1994) e InfoStat (Di Rienzo et al. 2013) se utilizaron para el análisis de datos.

\section{RESUltados}

Durante el periodo de estudio, las dosis diarias de la RUV solar variaron entre 45 y $2,200 \mathrm{~kJ} \mathrm{~m}^{-2}$ y la RFA entre $350 \mathrm{y}$ $13,900 \mathrm{~kJ} \mathrm{~m}^{-2}$, ambas con valores máximos en verano, principalmente en diciembre y enero (Fig. 2). La columna de agua 
resulting from the similarity analysis (Euclidean distance index) of the selected environmental variables were ordinated by a nonmetric multidimensional scaling (MDS) analysis. To examine the contribution of each taxon to the similarity within a group and dissimilarity between groups, a similarity percentage analysis (SIMPER) was applied using the Bray-Curtis similarity index. The PRIMER 5.0 software package (Clarke and Warwick 1994) and InfoStat software package (Di Rienzo et al. 2013) were used for data analysis.

\section{RESULTS}

During the study period, daily doses of solar UVR varied from 45 to $2,200 \mathrm{~kJ} \mathrm{~m}^{-2}$ and PAR from 350 to $13,900 \mathrm{~kJ} \mathrm{~m}^{-2}$, both with maximum values in summer, mainly in December and January (Fig. 2). The water column was considered mixed throughout the study period, temperature and salinity always being homogeneous. The surface water temperature ranged from 7 to $17^{\circ} \mathrm{C}$, while salinity oscillated between 30.0 and 32.4 (data not shown).

Total Chla concentration (Fig. 3) had the highest values in winter, particularly in August of 2010 and 2011 (6.2 and $6.6 \mu \mathrm{g} \mathrm{L}^{-1}$, respectively). Chla in the $<20-\mu \mathrm{m}$ fraction was high in spring and summer, representing about $80 \%$ of the total Chla. Flagellates were the most abundant group throughout the study period, especially in the summer of $2011\left(\sim 1,400\right.$ cells $\left.\mathrm{mL}^{-1}\right)$ and $2012\left(1,900\right.$ cells $\mathrm{mL}^{-1}, \sim 90 \%$ of cells), except in August 2011 when the abundance of diatoms was the highest $\left(\sim 2,000\right.$ cells $\mathrm{mL}^{-1}, 83 \%$ of cells $)$. The abundance of dinoflagellates was very low throughout the study period, with a maximum value of 67 cells $\mathrm{mL}^{-1}$ in December 2010, corresponding to $3.5 \%$ of the total abundance.

Copepods (juvenile and adults) were the most abundant group (Table 1) ( $>72 \%$ of total zooplankton in all samples, except for July and August of 2011). Copepod abundance varied between 380 ind $\mathrm{m}^{-3}$ (July 2011) and 20,700 ind $\mathrm{m}^{-3}$ (February 2012) for adults, and between 90 ind $\mathrm{m}^{-3}$ (August 2011) and 73,000 ind $\mathrm{m}^{-3}$ (February 2012) for nauplii. Polychaete larvae were abundant mainly in the winter and spring months, with a maximum abundance in October 2010 $\left(3,150\right.$ ind $\left.\mathrm{m}^{-3}\right)$. Appendicularians were only found in May 2012 with a density of $57 \mathrm{ind} \mathrm{m}^{-3}$. The abundance of barnacle nauplli was high mainly in autumn and winter, with a maximum abundance in April 2011 (460 ind $\mathrm{m}^{-3}$ ), while cladocerans were rather scarce in general, with a maximum abundance in September $2010\left(100 \mathrm{ind} \mathrm{m}^{-3}\right)$. The other groups (decapod larvae, amphipods, and ostracods) were found in a few samples and in very low abundances.

Among the copepods, harpacticoids and calanoids were more abundant than cyclopoids (Fig. 4). Calanoids were present throughout the cycle; however, harpacticoids dominated in the summer months and their densities were higher than those of calanoids. In particular, during January, the adults were more abundant, while in February the densities of adults se consideró mezclada a lo largo del periodo de estudio, y la temperatura y la salinidad siempre fueron homogéneas. La temperatura superficial del agua varió entre 7 y $17^{\circ} \mathrm{C}$, mientras que la salinidad osciló entre 30.0 y 32.4 (datos no mostrados).

La concentración de Chla total (Fig. 3) presentó los valores más altos en invierno, particularmente en agosto de 2010 y 2011 (6.2 y $6.6 \mathrm{mg} \mathrm{L}^{-1}$, respectivamente). La concentración de Chla de la fracción $<20 \mu \mathrm{m}$ fue alta en primavera y verano, ya que representó alrededor del $80 \%$ de la Chla total. Los flagelados fueron el grupo más abundante durante el periodo estudiado, sobre todo en verano de 2011 $\left(\sim 1,400\right.$ cél $\left.\mathrm{mL}^{-1}\right)$ y $2012\left(1,900\right.$ cél $\mathrm{mL}^{-1}, \sim 90 \%$ de las células), excepto en agosto de 2011 cuando la abundancia de diatomeas fue más alta ( 2,000 cél $\mathrm{mL}^{-1}, 83 \%$ de las células). La abundancia de dinoflagelados fue muy baja durante todo el periodo estudiado, con un valor máximo de $67 \mathrm{cél} \mathrm{mL}^{-1} \mathrm{en}$ diciembre de 2010, lo que correspondió al 3.5\% de la abundancia total.

Los copépodos (juveniles y adultos) fueron el grupo más abundante (Tabla 1) (>72\% del total del zooplancton en todas las muestras, excepto en julio y agosto de 2011). La abundancia de copépodos varió entre 380 ind $\mathrm{m}^{-3}$ (julio de 2011) y 20,700 ind $\mathrm{m}^{-3}$ (febrero de 2012) para adultos y de 90 ind $\mathrm{m}^{-3}$ (agosto de 2011) a 73,000 ind $\mathrm{m}^{-3}$ (febrero de 2012) para nauplios. Las larvas de poliquetos fueron abundantes principalmente en los meses de invierno y primavera, con la abundancia máxima en octubre de $2010\left(3,150\right.$ ind $\left.\mathrm{m}^{-3}\right)$. Las apendicularias solamente se encontraron en mayo de 2012

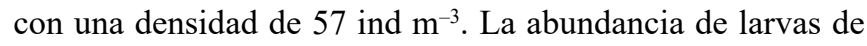
cirripedios fue alta principalmente en otoño e invierno y máxima en abril de 2011 (460 ind $\mathrm{m}^{-3}$ ), mientras que los cladóceros generalmente fueron escasos, con una abundancia máxima en septiembre de 2010 (100 ind $\left.\mathrm{m}^{-3}\right)$. Se encontraron otros grupos (larvas de decápodos, anfípodos y ostrácodos) en unas pocas muestras y en abundancias muy bajas.

Entre los copépodos, los harpacticoideos y los calanoideos fueron más abundantes que los ciclopoideos (Fig. 4). Los calanoideos estuvieron presentes durante todo el ciclo, sin embargo, los harpacticoideos dominaron en los meses de verano y sus densidades fueron más altas que las de los calanoideos. En particular, durante enero, los adultos fueron más abundantes que los copepoditos, mientras que en febrero las densidades de ambos fueron similares. Se registraron un total de 9 especies (Tabla 2) cuya abundancia mostró una marcada tendencia a lo largo del ciclo estacional. En invierno se encontraron más especies, principalmente los calanoideos Paracalanus parvus, Calanoides carinatus, Drepanopus forcipatus, Centropages brachiatus, Ctenocalanus vanus y Acartia tonsa, y los ciclopoideos Oithona nana y Oithona helgolandica. En verano se observaron A. tonsa, P. parvus y Euterpina acutifrons, siendo esta última la dominante (90\%). En otoño, A. tonsa y P. parvus fueron las especies dominantes. Los valores más altos de la riqueza (índice de Margalef, d) y el índice de Shannon-Wiener $\left(H^{\prime}\right)$ se registraron en los 

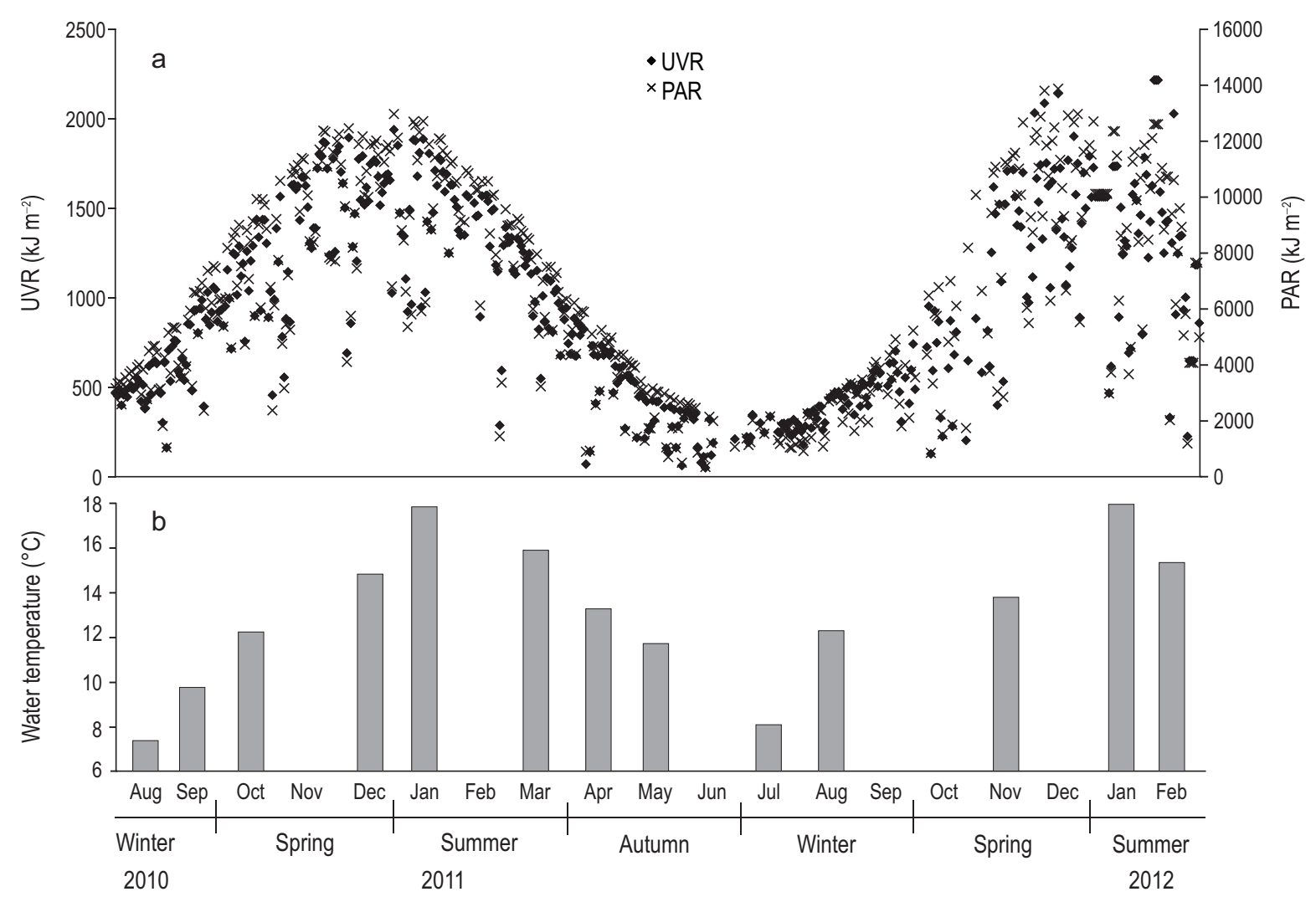

Figure 2. (a) Surface dose $\left(\mathrm{kJ} \mathrm{m}^{-2}\right)$ of solar ultraviolet radiation (UVR, 280-400 nm, black diamonds) and photosynthetically active radiation (PAR, 400-700 nm, black crosses) and (b) surface water temperature $\left({ }^{\circ} \mathrm{C}\right.$ ) at the study site during the period August $2010-$ February 2012.

Figura 2. (a) Dosis $\left(\mathrm{kJ} \mathrm{m}^{-2}\right)$ de la radiación solar ultravioleta (UVR, 280-400 nm, diamantes negros) y la radiación fotosintéticamente activa (PAR, 400-700 nm, cruces negras) y (b) temperatura $\left({ }^{\circ} \mathrm{C}\right)$ superficial del agua en el sitio de estudio durante el periodo agosto $2010-$ febrero 2012.

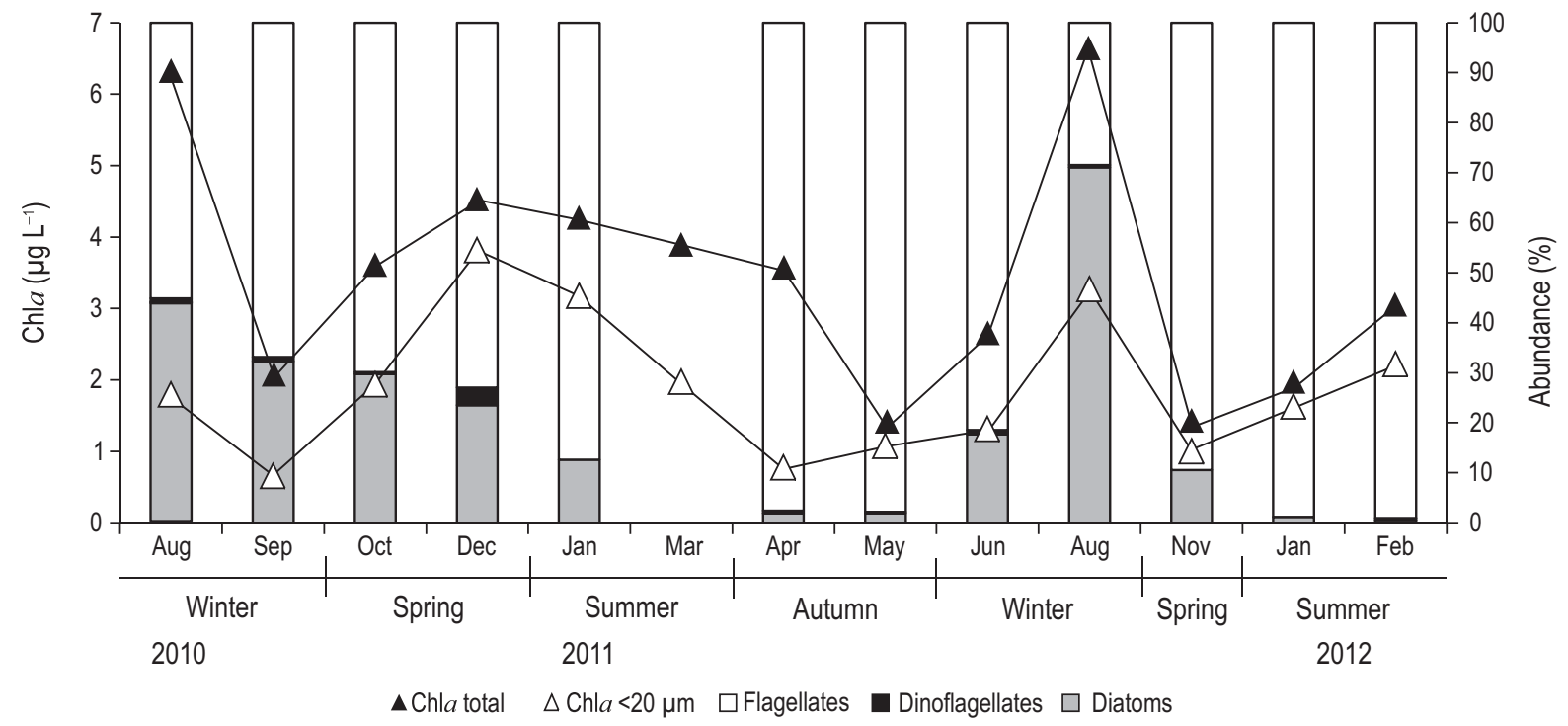

Figure 3. Concentration $\left(\mu \mathrm{g} \mathrm{L} \mathrm{L}^{-1}\right)$ of chlorophyll $a$ (Chla; total fraction [black triangles] and pico- and nanoplankton $[<20 \mu \mathrm{m}$, white triangles]), and percent abundance of flagellates (in white), dinoflagellates (in black), and diatoms (in gray) from samples collected from August 2010 to February 2012 at the northern Patagonian coastal station. Data are not available for September, October, and December 2011.

Figura 3. Concentración $\left(\mu \mathrm{g} \mathrm{L}{ }^{-1}\right)$ de clorofila $a(C h l a$; fracción total [triángulos negros]; y pico y nanoplancton $[<20 \mu \mathrm{m}$, triángulos blancos]) y el porcentaje de abundancia de flagelados (en blanco), dinoflagelados (en negro) y diatomeas (en gris) a partir de las muestras recolectadas en el periodo agosto 2010-febrero 2012 en la estación costera en Patagonia norte. Datos no disponibles para septiembre, octubre y diciembre de 2011. 
Spinelli et al.: Diversity of copepods in Patagonian coastal waters

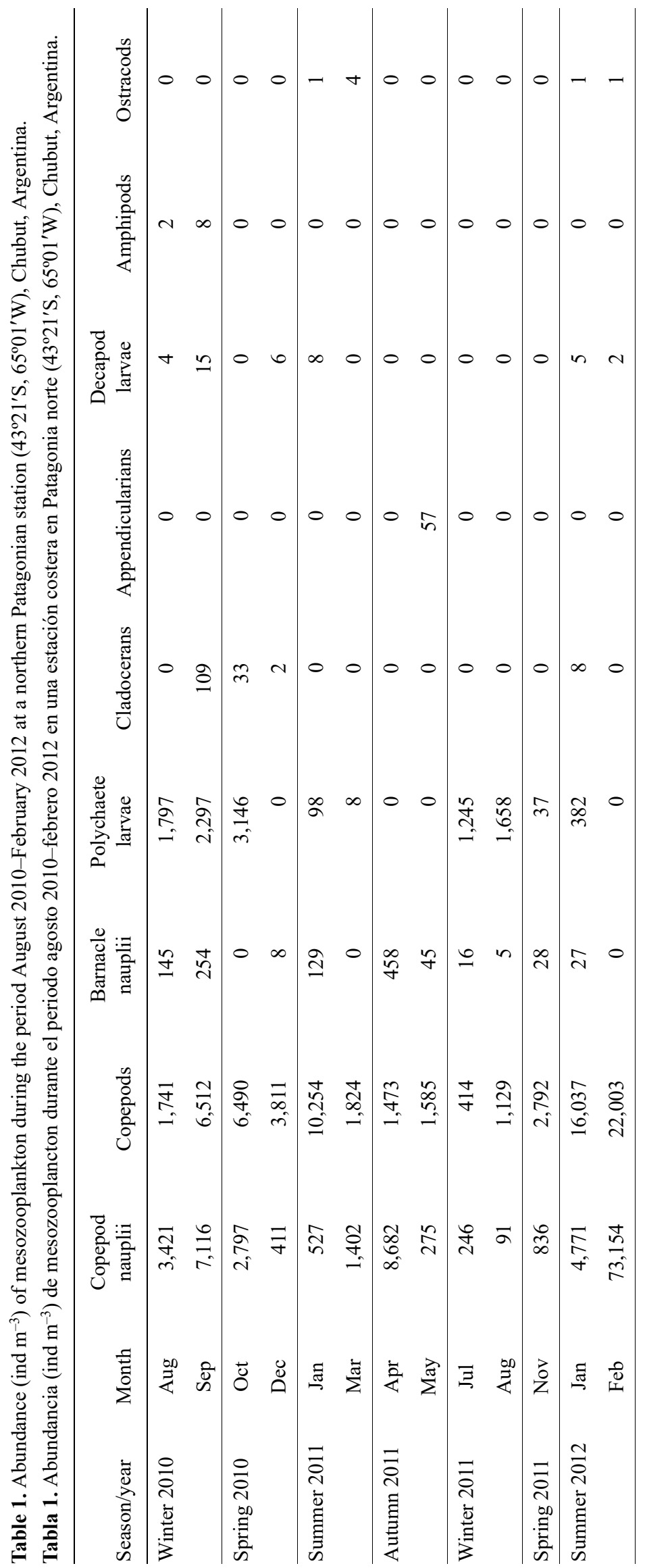


and copepodites were similar. A total of 9 species were recorded (Table 2), showing a marked tendency throughout the seasonal cycle. Most species were observed in winter, mainly the calanoids Paracalanus parvus, Calanoides carinatus, Drepanopus forcipatus, Centropages brachiatus, Ctenocalanus vanus, and Acartia tonsa, and the cyclopoids Oithona nana and Oithona helgolandica. In summer, A. tonsa, P. parvus, and Euterpina acutifrons were observed, the last one being dominant ( $\sim 90 \%)$. In autumn, $A$. tonsa and $P$. parvus were dominant. The highest richness (Margalef index, d) and Shannon-Wiener index $\left(H^{\prime}\right)$ values were recorded in the winter and spring months, whereas the lowest values were recorded in the summer months; the equitability index $\left(J^{\prime}\right)$ showed a similar pattern.

The dominant calanoid species during the study period were E. acutifrons, P. parvus, and A. tonsa. The mean prosome length of $E$. acutifrons varied between 170 and $950 \mu \mathrm{m}(526 \pm 200 ; n=355)$ (Fig. 5), with the largest individuals found in summer (i.e., mostly mature individuals, especially egg-carrying females). Similarly, the mean prosome length of $P$. parvus varied from 190 to $1,190 \mu \mathrm{m}$ ( $540 \pm 234 ; n=380$ ), while the sizes of $A$. tonsa (copepodites and adults) oscillated between 150 and $1700 \mu \mathrm{m}(688 \pm 293$; $n=488$ ), being larger in winter.

The PCA results are shown in Figure 6. The abundances of the copepods C. vanus, D. forcipatus, C. brachiatus, A. tonsa, and $O$. helgolandica were correlated, mainly in the winter months. The abundance of $C$. carinatus was positively correlated with that of diatoms $(r=0.73 ; P<0.05)$ and negatively correlated with sea surface temperature and UVR $(r=-0.77$ and $r=-0.73$, respectively; $P<0.05$ ). The abundance of E. acutifrons was positively correlated with UVR, PAR, temperature, and the concentration of flagellates $(r=$ $0.61, r=0.58, r=0.64$, and $r=0.72$, respectively; $P<0.05$ ). The abundance of $P$. parvus was positively correlated with the concentration of flagellates $(r=0.67 ; P<0.05)$ and with the abundance of $E$. acutifrons $(r=0.71 ; P<0.05)$. The diversity indices $\left(d, J^{\prime}\right.$, and $\left.H^{\prime}\right)$ were negatively correlated with temperature ( $r=-0.73, r=-0.69$, and $r=-0.82$, respectively; $P<0.05$ ). The PCA showed that UVR, PAR, and temperature were mainly correlated with principal component 1 (Table 3), separating the samples according to the seasons.

Four groups of samples were determined at $80 \%$ level of similarity, corresponding to winter, spring, summer, and autumn (Fig. 7a). The MDS analysis confirmed the assemblages with a stress value of 0.11 (Fig. $7 b$ ). In summer and spring (groups 2 and 3), E. acutifrons and A. tonsa were the dominant species, the former being the most abundant (86\%) mainly in January, February, and March (summer). In group 1 (winter: August and July), C. carinatus and P. parvus were the dominant species ( $62 \%$ and $30 \%$, respectively), while in group 4 (autumn: April and May), A. tonsa and P. parvus were the dominant species $(59.60 \%$ and $40.40 \%$, respectively). However, when considering the abiotic variables (temperature and UVR), the MDS separated the assemblages
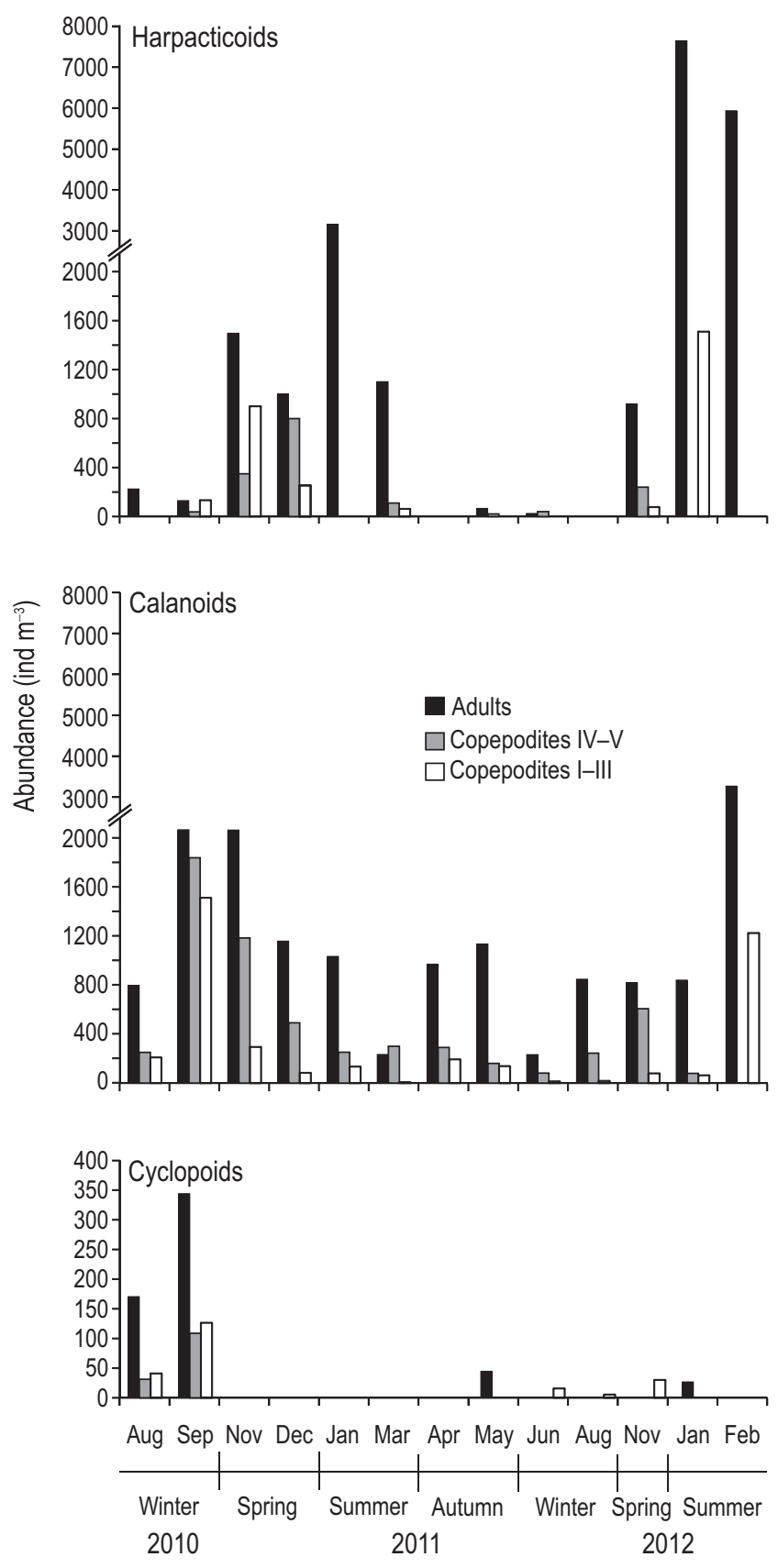

Figure 4. Abundance (ind $\mathrm{m}^{-3}$ ) of adults (black bars) and copepodites IV-V (gray bars) and I-III (white bars) of harpacticoids (a), calanoids (b), and cyclopoid copepods (c) during August 2010-February 2012 at the northern Patagonian coastal station. Note the different scales on the $y$ axis for cyclopoids.

Figura 4. Abundancia (ind $\mathrm{m}^{-3}$ ) de adultos (barras negras), copepoditos IV-V (barras grises) y copepoditos I-III (barras blancas) de copépodos harpacticoideos (a), calanoideos (b) y ciclopoideos (c) durante el periodo de agosto de 2010 a febrero de 2012 en la estación costera en Patagonia norte. Nótese la diferente escala en el eje $y$ para los ciclopoideos. 
Spinelli et al.: Diversity of copepods in Patagonian coastal waters

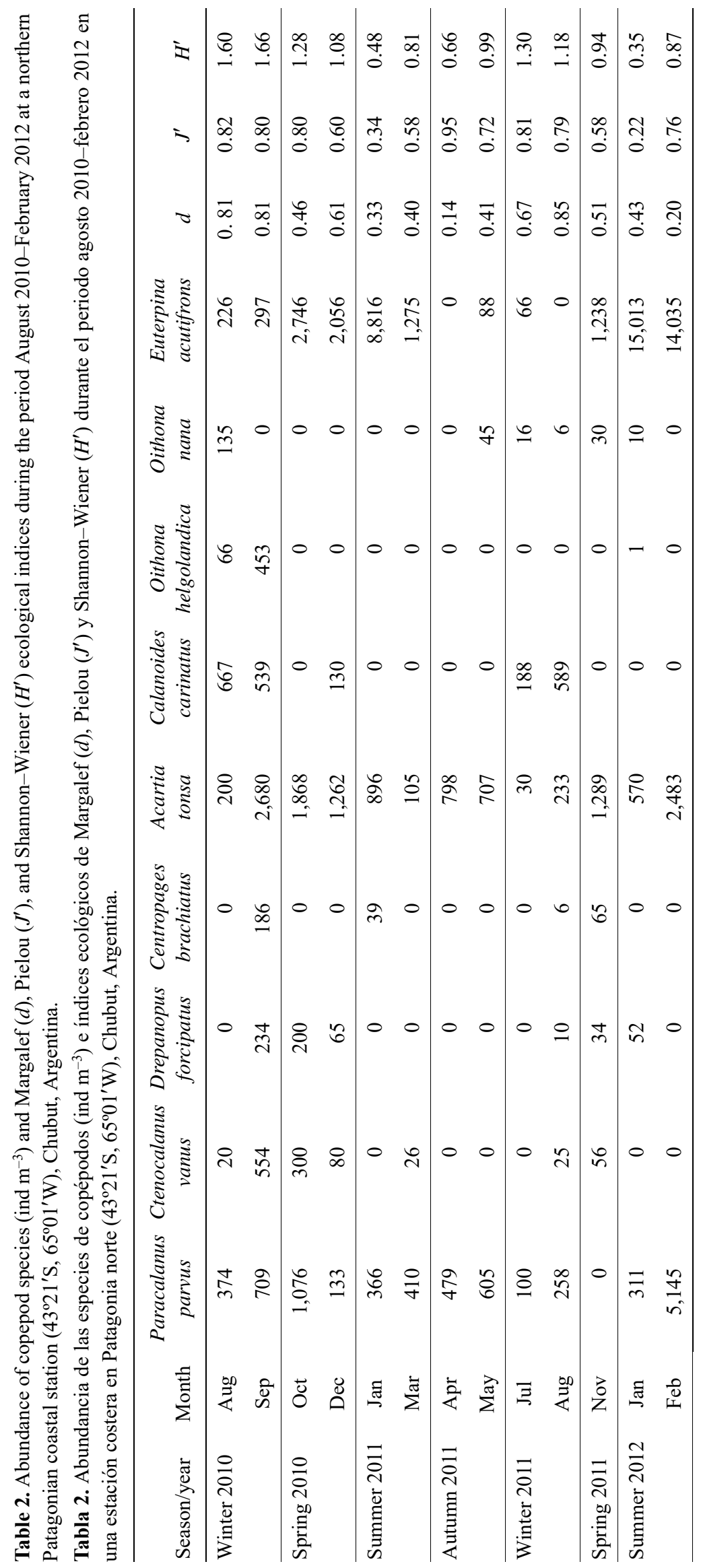




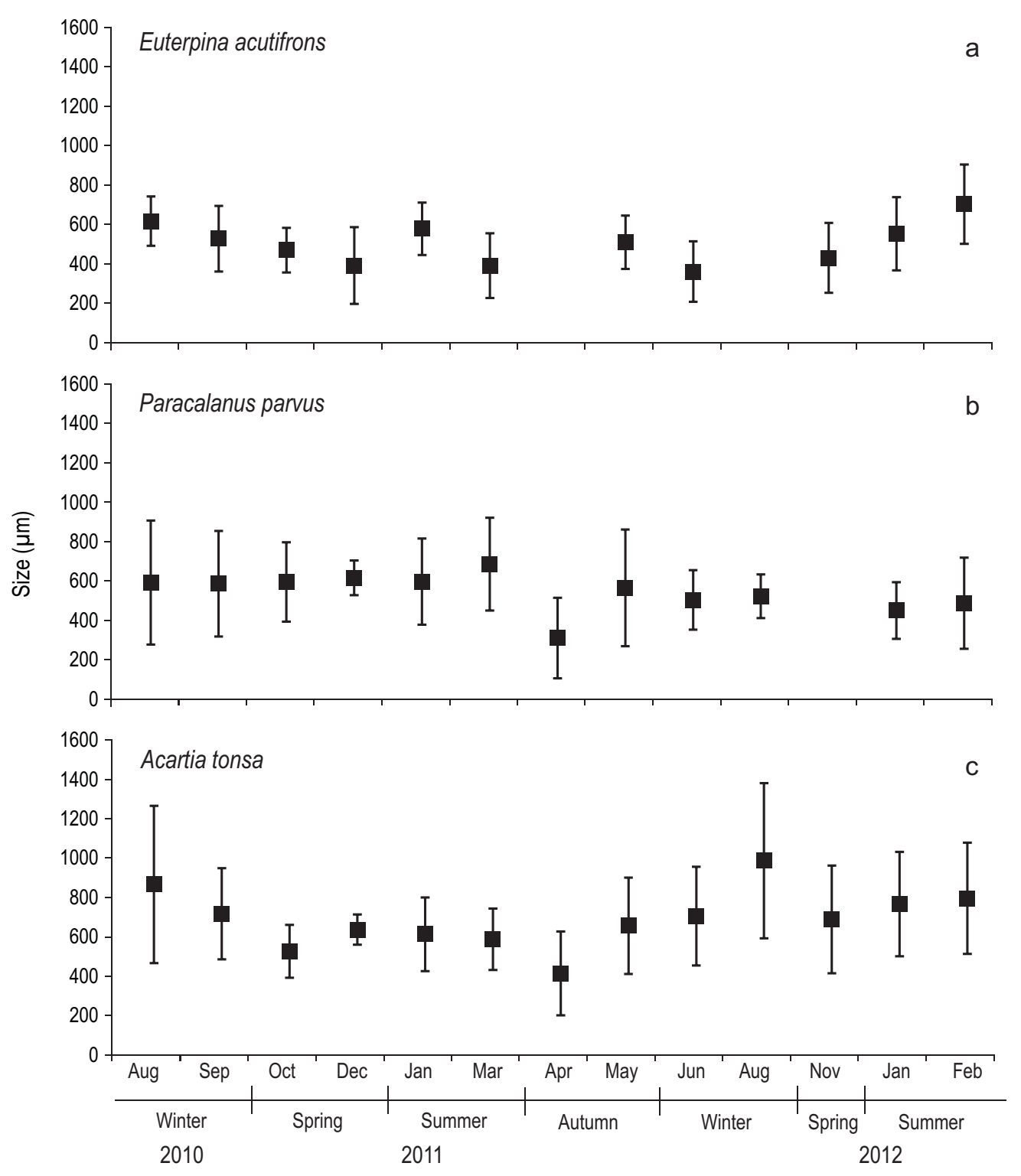

Figure 5. Size structure ( $\mu \mathrm{m}$ ) of Euterpina acutifrons (a), Paracalanus parvus (b), and Acartia tonsa (c) during August 2010-February 2012 at the northern Patagonian coastal station. The lines on top of the mean (black squares) indicate the standard deviation.

Figura 5. Estructura de tallas $(\mu \mathrm{m})$ de Euterpina acutifrons (a), Paracalanus parvus (b) y Acartia tonsa (c) durante agosto 2010-febrero 2012 en la estación costera en Patagonia norte. Las líneas sobre la media (cuadros negros) indican la desviación estándar.

into two groups (autumn/winter and spring/summer), mainly because there is a very pronounced gradient in these variables during these two periods of the year (Fig. 7c).

\section{DISCUSSION}

Copepods were the dominant metazooplankton group at the study site, as observed in other temperate coastal regions (Hopcroft et al. 2001, Aguirre et al. 2012). Copepods play a key role in the pelagic carbon flux because of their capability of taking up energy from the microbial food web and transferring it to higher trophic levels (Turner 2004, Viñas et al. 2013). All the copepod species found in this study have meses de invierno y primavera, mientras que los valores más bajos se determinaron en los meses de verano; el índice de equitatividad $\left(J^{\prime}\right)$ mostró un patrón similar.

Euterpina acutifrons, $P$. parvus y A. tonsa fueron las especies dominantes durante el periodo estudiado. La longitud media del prosoma de E. acutifrons varió entre $170 \mathrm{y}$ $950 \mu \mathrm{m}(526 \pm 200 ; n=355)$ (Fig. 5), y los individuos más grandes fueron encontrados en verano (individuos maduros, principalmente hembras con huevos). Del mismo modo, las tallas de $P$. parvus variaron entre 190 y $1,190 \mu \mathrm{m}(540 \pm 234$; $n=380$ ), y las tallas de $A$. tonsa (copepoditos y adultos) oscilaron entre 150 and $1700 \mu \mathrm{m}(688 \pm 293 ; \mathrm{n}=488)$, siendo mayores en invierno. 


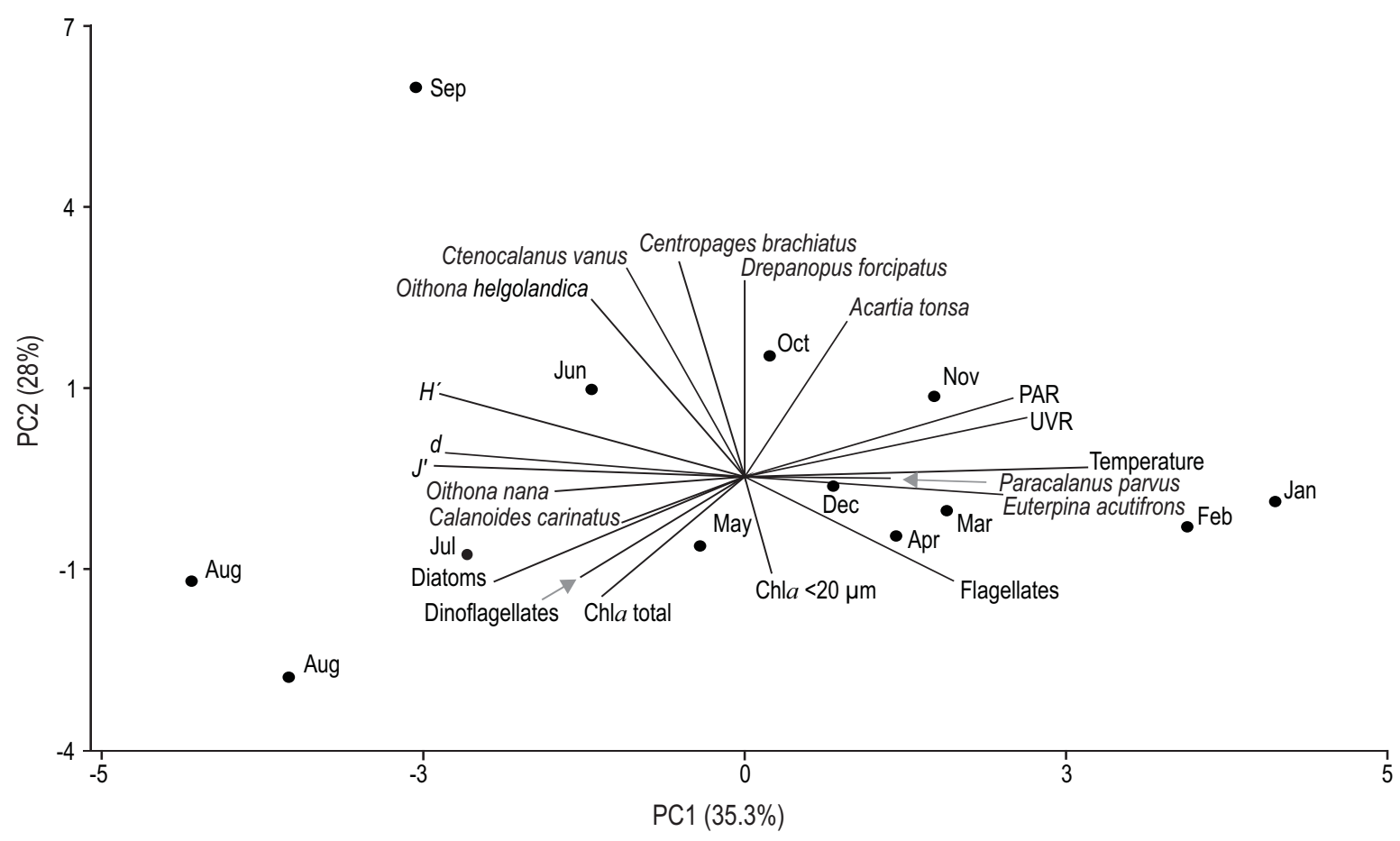

Figure 6. Principal component analysis (PCA) between species of copepods, phytoplankton groups (diatoms, flagellates, and dinoflagellates), chlorophyll $a$ (Chla, total fraction and pico-nanoplankton fraction), abiotic variables (temperature, ultraviolet radiation [UVR], photosynthetically active radiation [PAR]) and diversity indices $\left(d, J^{\prime}\right.$, and $\left.H^{\prime}\right)$ during August 2010-February 2012 at the northern Patagonian coastal station.

Figura 6. Análisis de componentes principales (PCA) entre las especies de copépodos, grupos de fitoplancton (diatomeas, flagelados y dinoflagelados), clorofila a (Chla, fracción total y de pico y nanoplancton), variables abióticas (temperatura, radiación ultravioleta [UV] y radicación fotosintéticamente activa [PAR]) y los índices de diversidad ( $d, J^{\prime}$ y $H^{\prime}$ ) registrados durante agosto 2010-febrero 2012 en la estación costera en Patagonia norte.

previously been reported for the Valdés Peninsula, Chubut Province (Sabatini and Martos 2002, Spinelli et al. 2012), except for E. acutifrons. This species is a small pelagic harpacticoid that often numerically dominates the mesoplanktonic community in coastal and estuarine ecosystems (Sautour and Castel 1995, Eskinazi-Sant'Anna and Björnberg 2006).

Our results highlight the strong temporal variation in species composition and copepod abundance. Two different periods were found throughout the cycle, spring/summer and autumn/winter, with differences clearly marked by biotic and abiotic variables. The highest diversity of copepod species and abundance of polychaete larvae occurred in winter, likely related to the relatively high concentration of total Chla (i.e., bloom onset period) that favored the co-existence of more species of copepods. In spring/summer, under high radiation and temperature levels, flagellates (potential prey for copepods) were dominant in terms of abundance; therefore, the populations of small species such as the harpacticoid E. acutifrons became the most abundant. In agreement with our results, Villafañe et al. $(2004,2013)$ recorded maximum Chla values in winter; we were unable to collect stratification data (CTD profiles) during winter, but these authors observed
Los resultados del ACP (Fig. 6) mostraron que las abundancias de los copépodos C. vanus, D. forcipatus, C. brachiatus, A. tonsa y O. helgolandica se correlacionaron, principalmente en los meses de invierno. La abundancia de C. carinatus se correlacionó positivamente con la concentración de diatomeas $(r=0.73, P<0.05)$ y negativamente con la temperatura superficial del mar y RUV $(r=-0.77$ y $r=$ -0.73 , respectivamente; $P<0.05$,). Por otro lado, la abundancia de E. acutifrons se correlacionó positivamente con las dosis de RUV y RAF, la temperatura y la concentración de flagelados $(r=0.61, r=0.58, r=0.64$ y $r=0.72$, respectivamente; $P<0.05$ ). Además, la abundancia de $P$. parvus se correlacionó positivamente con la concentración de flagela$\operatorname{dos}(r=0.67 ; P<0.05)$ y con la abundancia de E. acutifrons $(r=0.71 ; P<0.05)$. Los índices de diversidad $\left(d, J^{\prime}\right.$ y $\left.H^{\prime}\right)$ se correlacionaron negativamente con la temperatura $(r=-0.73$, $r=-0.69$ y $r=-0.82$, respectivamente; $P<0.05$ ). El ACP demostró que la RUV, RAF y la temperatura se correlacionaron principalmente con el componente principal 1 (Tabla 3), que separa las muestras de acuerdo con las estaciones del año. Con un $80 \%$ de similitud, se determinaron 4 grupos, que correspondieron al invierno, primavera, verano y otoño (Fig. 7a). El análisis MDS confirmó los mismos resultados 
Table 3. Results of the principal components analysis. Eigenvectors (EV), eigenvalues, percent of the variance explained by the original dataset $\left(r^{2}\right)$, and correlation ( $r$ ) of the original variables with the first two principal components (PC1 and PC2).

Tabla 3. Resultados del ánalisis de componentes principales. Autovector (EV), autovalores, porcentaje de la varianza explicada por el set de datos $\left(r^{2}\right)$ y correlación ( $r$ ) con las variables originales con los dos primeros componentes (PC1 y PC2).

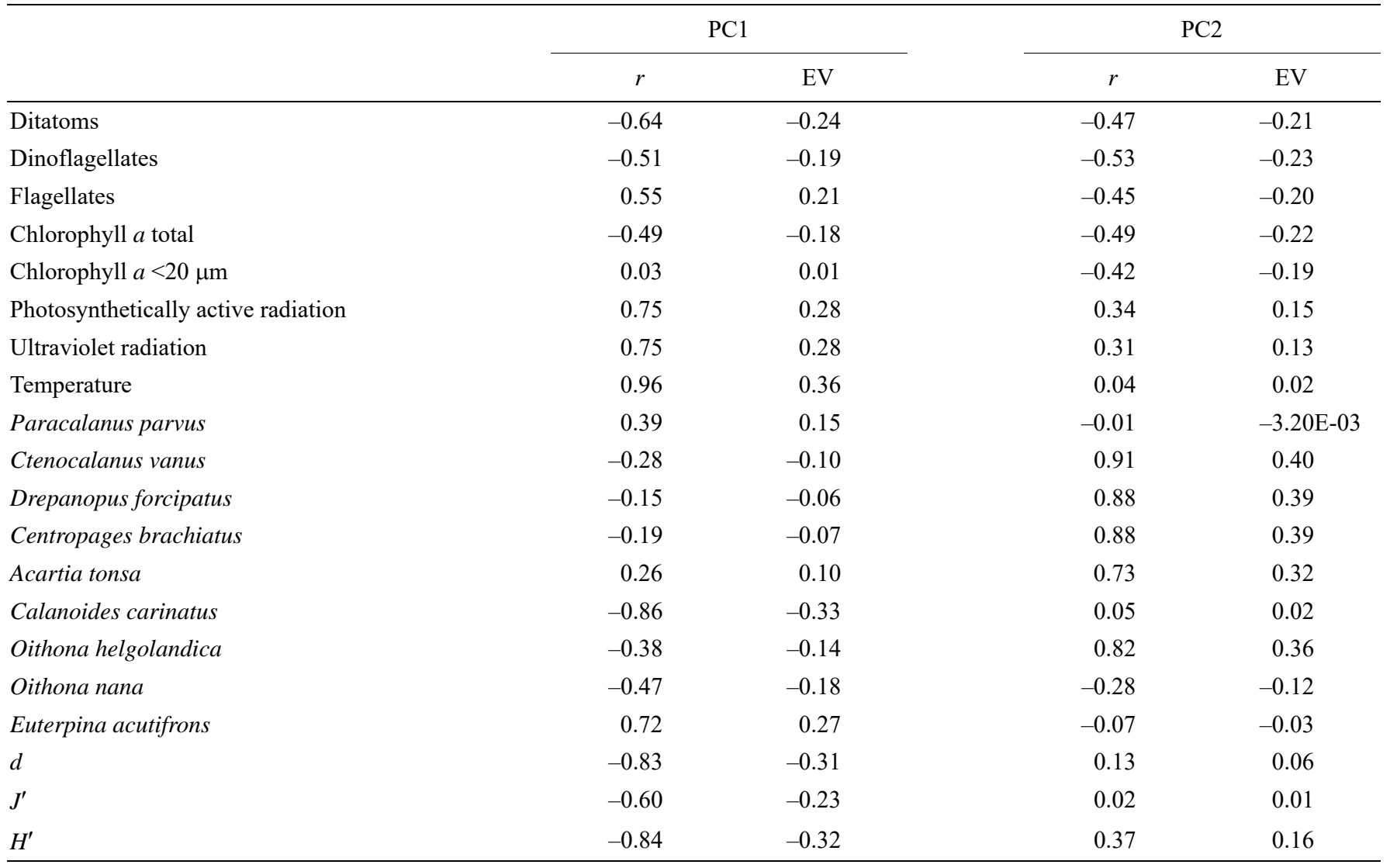

a phytoplankton bloom, associated with favorable stratification, lower radiation, and temperature conditions. On the other hand, E. acutifrons, $A$. tonsa, and $P$. parvus were associated with flagellates, and this concurs with the observations made by Uye and Shibuno (1992) and Guisande et al. (2000). Similar results were also obtained experimentally by Vargas and González (2004). They detected that A. tonsa feeds on diatoms and flagellates and that $P$. parvus feeds on flagellates. The abundance of $C$. carinatus was positively correlated with that of diatoms and it is known that this species has typically been associated with this group of phytoplankton (Lopes et al. 1999). Taking into consideration that the calanoid species found were primarily herbivorous, a classical food chain can be suggested for winter, with large copepods such as $C$. carinatus associated with a higher concentration of diatoms.

A similar result was found in coastal waters of the northern Argentinean Sea (EPEA station, 38 $28^{\prime} \mathrm{S}, 5^{\circ} 41^{\prime} \mathrm{W}$ ), where the zooplankton succession also exhibited two main periods throughout the year: a cold winter/spring period characterized by a dominant classical herbivorous food web (with high Chla concentrations) and a warm summer period, con un valor de stress de 0.11 (Fig. 7b). En verano y primavera (grupos 2 y 3), E.acutifrons y A. tonsa fueron las especies dominantes, siendo la primera la más abundante (86\%) principalmente en enero, febrero y marzo (verano). Las especies dominantes en el grupo 1 (invierno: julio y agosto) fueron $C$. carinatus y $P$. parvus $(62 \%$ y $30 \%$, respectivamente), y en el grupo 4 (otoño: abril y mayo) las especies dominantes fueron $A$. tonsa y $P$. parvus $(59.60 \%$ y $40.40 \%$, respectivamente). Sin embargo, al considerar las variables abióticas (temperatura y RUV), el MDS separa los conjuntos en dos grupos (otoño/invierno y primavera/verano), principalmente porque hay un gradiente muy pronunciado de estas variables durante estos dos periodos del año (Fig. 7c).

\section{DISCUSIÓN}

Los copépodos fueron el grupo de metazooplancton dominante en el sitio estudiado, como se ha observado en otras regiones costeras templadas (Hopcroft et al. 2001, Aguirre et al. 2012). Los copépodos juegan un papel clave en el flujo de carbono pelágico debido a su capacidad para tomar la energía de la red trófica microbiana y transferirla a los 

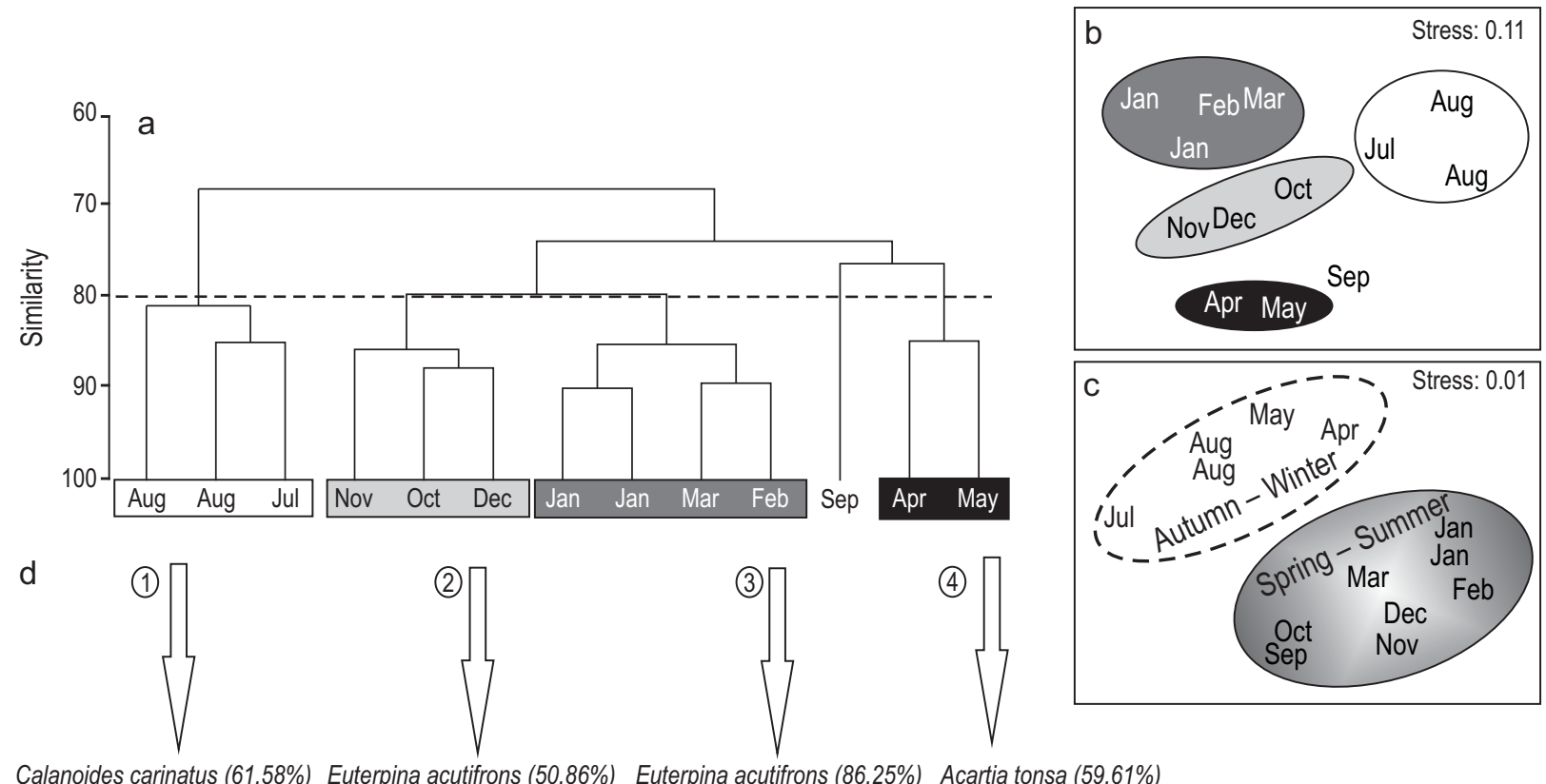

Paracalanus parvus (29.58\%)
Acartia tonsa (44.22\%)

Paracalanus parvus (40.39\%)

Spring - Summer

Figure 7. Analysis of similarity among the sampling dates. Cluster analysis (Bray-Curtis index) (a), and multidimensional scaling of samples using (b) biological and (c) abiotic variables (Euclidean distance index). The copepod species representative of each of the groups according to the SIMPER analysis are indicated with arrows $(\mathbf{d})$.

Figura 7. Análisis de similitud analizados entre las fechas de muestreo. Análisis de agrupación (índice Bray-Curtis) (a), y escalamiento multidimensional de las muestras utilizando variables (b) biológicas (índice de distancia euclidea) y (c) abióticas. Se indican con flechas las especies de copépodos representativas de cada uno de los grupos según el análisis de SIMPER (d).

dominated by picophytoplankton, in which smaller species such as O. nana and Paracalanus spp. were present (Viñas et al. 2013). However, temporal variations in copepod abundance may be explained not only by the availability of phytoplankton (bottom-up mechanism) but also by predation. In the study area, potential predators such as ctenophores and chaetognaths are very abundant (Mianzán and Guerrero 2000), and there is a high abundance of anchovy larvae (Hansen et al. 2001, Spinelli et al. 2012). On the other hand, Calbet et al. (2001) studied the seasonal succession of copepods in the coastal zone off Blanes (northwestern Mediterranean) and found differences in succession when compared to other coastal areas of the Mediterranean. These authors attribute the differences to the particularity of coastal areas. Coastal environments are highly variable and complex, and exposed to different intensities of anthropogenic and land-related influences (sewage discharges, rivers, etc.). The particular conditions of each location (oceanic currents, degree of enclosure, presence of submarine canyons, eddies, etc.) may strongly influence the annual distribution of phytoplankton and zooplankton (Calbet et al. 2001 and references therein).

Temperature and food quantity and quality are among the most important factors affecting egg production rates of niveles tróficos superiores (Turner 2004, Viñas et al. 2013). Todas las especies de copépodos que encontramos durante el estudio han sido registradas previamente para la península Valdés, provincia de Chubut (Sabatini y Martos 2002, Spinelli et al. 2012), a excepción de E. acutifrons. Esta especie es un pequeño harpacticoideo pelágico que a menudo domina numéricamente la comunidad mesoplanctónica de los ecosistemas costeros y de estuario (Sautour y Castel 1995, Eskinazi-Sant'Anna y Björnberg, 2006).

Nuestros resultados ponen de manifiesto una fuerte variación temporal en la composición y abundancia de las especies de copépodos. Se encontraron dos periodos diferentes a lo largo del ciclo, primavera/verano y otoño/invierno, con diferencias claramente señaladas tanto en variables bióticas como abióticas. La mayor diversidad de especies de copépodos y la mayor abundancia de larvas de poliquetos se encontraron en invierno, probablemente relacionado con la alta concentración de Chla total (i.e, periodo de inicio de floración) que favoreció la coexistencia de más especies de copépodos. En el periodo primavera/verano, se registraron altos niveles de radiación y de temperatura, y dominaron en términos de abundancia los flagelados (presa potencial de copépodos); por lo tanto, las poblaciones de especies pequeñas, como el harpacticoideo E. acutifrons fueron más abundantes. En 
marine copepods (Hirst and Bunker 2003, Gislason et al. 2008). Intensive reproduction of the small copepods $E$. acutifrons and P. parvus took place in summer, as indicated by the peaks of nauplii. This is probably related to the already known reproductive cycle of small copepod species in temperate seas (Pittois et al. 2009), which is positively controlled by temperature. The egg production rate increases exponentially with an increase in temperature (Vidal 1980, Uye and Shibuno 1992). Also, the high abundance of copepodites of E. acutifrons found in our study during the summer indicates active reproduction at this time of the year, in agreement with Viñas and Gaudy (1996), who observed mature organisms during the period of highest temperature in the San Matías Gulf (also in northern Patagonia). At low temperatures, the adults of this species remain in a state of quiescence (D'Apolito and Stancyk 1979, Viñas and Gaudy 1996), which would explain the low abundances during the winter time. This shows that even a small variation in temperature may considerably affect the population dynamics of E. acutifrons. Moreover, the larger sizes of A. tonsa were found when sea temperature was lower. This is consistent with observations from other studies in which prosome length was negatively correlated with temperature (Chinnery and Williams 2004, Hansen et al. 2010).

Finally, in our study, a high diversity of species was found in winter when the UVR was low. Since UVR has, in general, negative effects on phytoplankton, it may alter the quantity and quality of food, which in turn may reduce survival, growth, and reproduction of zooplankton (Hessen et al. 1997). Al-Aidaroos et al. (2015) recently reported that in the Red Sea the mortality rates of zooplankton increased greatly under UVR but declined when UVR was removed. Previous research in our study area addressing the effects of UVR has only been carried out on crab larvae (Hernández-Moresino et al. 2011, 2014; Gonçalves et al. 2014). Our work is the first study that considers the zooplankton community, especially the copepods, and natural variations with environmental factors. This highlights the potential importance of the effects of solar radiation on marine zooplankton from this area, and the need of performing longer-term studies considering natural communities and seasonal variations in solar radiation. Hence, the low diversity found in summer could be due to species-specific effects of detrimental solar radiation. This is the first study that reports the annual cycle of zooplankton in this productive area and our observations regarding the variation of copepod species at this northern Patagonian coastal station suggest different life-history strategies for this area. Evidently, more studies with a better temporal resolution are required to gain a deeper understanding about the interannual variability of this community, which in turn will help to interpret the effects of global climate change that are particularly relevant in high-latitude environments. coincidencia con nuestros resultados, Villafañe et al. (2004, 2013) encontraron valores máximos de Chla en invierno; nosotros no recolectamos datos de la estratificación (perfiles de CTD) durante el invierno, pero estos autores han observado una floración de fitoplancton asociada con condiciones favorables a la estratificación, y la menor radiación y temperatura. Por otro lado, E. acutifrons, A. tonsa y $P$. parvus se asociaron con los flagelados, lo cual concuerda con la observaciones realizadas por Uye y Shibuno (1992) y Guisande et al. (2000). Además, resultados similares fueron observados experimentalmente por Vargas y González (2004). Ellos han detectado que $A$. tonsa se alimenta de diatomeas y flagelados y que $P$. parvus se alimenta de flagelados. La abundancia de C. carinatus se correlacionó positivamente con la de diatomeas y se sabe que esta especie se ha asociado típicamente con este grupo de fitoplancton (Lopes et al. 1999). Tomando en cuenta que las especies de calanoideos que se encontraron fueron principalmente herbívoros, se puede sugerir que existe una cadena trófica clásica en invierno en la cual los copépodos grandes como C. carinatus están asociados con una alta concentración de diatomeas.

Resultados similares fueron encontrados en aguas costeras del norte del mar Argentino (estación EPEA, 38 $28^{\prime} \mathrm{S}$, $57^{\circ} 41^{\prime} \mathrm{W}$ ), donde la sucesión de zooplancton exhibió también dos periodos principales durante todo el año: un periodo de invierno/primavera caracterizado por una red trófica clásica herbívora (con altas concentraciones de Chla) y un periodo cálido de verano, con predominio de picofitoplancton, en el cual las especies más pequeñas como O. nana y Paracalanus spp. estuvieron presentes (Viñas et al. 2013). Sin embargo, la variación temporal de la abundancia de copépodos no se podría explicar sólo por la disponibilidad de fitoplancton (mecanismo de abajo a arriba [bottom up]), sino también por la depredación. En el área de estudio, los potenciales depredadores, tales como ctenóforos y quetognatos, son muy abundantes (Mianzán y Guerrero 2000), y también se ha registrado una alta abundancia de larvas de anchoíta (Hansen et al. 2001, Spinelli et al. 2012). Por otro lado, Calbet et al. (2001) estudiaron la sucesión estacional de copépodos en la zona costera de Blanes (Mediterráneo noroeste) y hallaron diferencias en la sucesión cuando se comparó con otras zonas costeras del Mediterráneo. Estos autores atribuyen las diferencias a la particularidad de las zonas costeras. Los ambientes costeros son muy variables y complejos y están expuestos a diferentes intensidades de influencias antropogénicas y de la tierra (descargas de aguas residuales, ríos, etc.). Las condiciones particulares de cada lugar (corrientes oceánicas, el grado de aislamiento, la presencia de cañones submarinos, remolinos, etc.) pueden influir fuertemente en la distribución anual del fitoplancton y zooplancton (Calbet et al. $2001 \mathrm{y}$ referencias allí citadas).

La temperatura y la cantidad y calidad de los alimentos, son algunos de los factores más importantes que afectan a las tasas de producción de huevos de copépodos marinos (Hirst y 


\section{ACKNOWLEDGMENTS}

MLS was supported by a doctoral scholarship from Consejo Nacional de Investigaciones Científicas y Técnicas (CONICET, Argentina) and this paper was submitted in partial fulfillment of the doctoral degree requirements. This work was supported by UBACYT 20020100200048 and CONICET PIP 112201 10100351. Macarena Valiñas and Sebastian Strauch assisted during sampling, and Sergio Fernández (Estación Marítima) provided logistics at the time of sampling. We thank Walter Helbling for advice and support, and the Cooperativa Eléctrica y de Servicios de Rawson for providing building infrastructure. This is Contribution 157 of Estación de Fotobiología Playa Unión.

\section{REFERENCES}

Aguirre GE, Capitanio FL, Lovrich GA, Esnal GB. 2012. Seasonal variability of metazooplankton in coastal sub-Antarctic waters (Beagle Channel). Mar. Biol. Res. 8: 341-353.

Al-Aidaroos AM, El-Sherbiny MMO, Satheesh S, Mantha G, Agustī S, Carreja B, Duarte CM. 2014. High mortality of Red Sea zooplankton under ambient solar radiation. PLOS One. http://dx.doi.org/10.1371/journal.pone.0108778.1

Antacli JC, Hernández D, Sabatini ME. 2010. Estimating copepods' abundance with paired nets: Implications of mesh size for population studies. J. Sea Res. 67: 71-77.

Barbieri ES, Villafañe VE, Helbling EW. 2002. Experimental assessment of UV effects upon temperate marine phytoplankton when exposed to variable radiation regimes. Limnol. Oceanogr. 47: 1648-1655.

Bancroft BA, Baker NJ, Blaustein AR. 2007. Effects of UVB radiation on marine and freshwater organisms: A synthesis through meta-analysis. Ecol. Lett. 10: 332-345.

Boltovskoy D. 1999. South Atlantic Zooplankton. Backhuys Publishers, Leiden, Netherlands, 1706 pp.

Bradford-Grieve JM, Markoseva EL, Rocha CEF, Abichi B. 1999. Copepoda. In: Boltovskoy D (ed.), South Atlantic Zooplankton. Backhuys Publishers, Leiden, Netherlands, pp. 869-1098.

Bray RJ, Curtis JT. 1957. An ordination of the upland forest communities of southern Wisconsin. Ecol. Monogr. 27: $325-349$

Calbet A, Garrido S, Saiz E, Alcaraz M, Duarte CM. 2001. Annual zooplankton succession in coastal NW Mediterranean waters: The importance of the smaller size fractions. J. Plankton Res. 23: 319-331.

Chinnery FE, Williams JA. 2004. The influence of temperature and salinity on Acartia (Copepoda: Calanoida) nauplii survival. Mar. Biol. 145: 733-738.

Clarke K, Warwick R. 1994. Change in marine communities: An Approach to Statistical Analysis and Interpretation. Natural Environment Research Council, Plymouth Marine Laboratory, Plymouth, 144 pp.

D'Apolito LM, Stancyk SE, 1979. Population dynamics of Euterpina acutifrons (Copepoda: Harpacticoida) from North Inlet, South Carolina, with reference to dimorphic males. Mar. Biol. 54: 251-260.

De Carli P, Braccalenti J, García de León FJ, Acuña-Gómez, EP. 2012. La pesquería del langostino argentino Pleoticus muelleri (Crustacea: Penaeidae) en Patagonia. ¿Un único stock? An. Inst. Patagonia 40: 103-112.
Bunker 2003, Gislason et al. 2008). Una reproducción intensa de los copépodos pequeños E. acutifrons y P. parvus ocurrió en verano, según lo evidenciado por la alta abundancia de nauplios. Esto está probablemente relacionado con el ya conocido ciclo reproductivo de las pequeñas especies de copépodos en los mares templados (Pittois et al. 2009), el cual es controlado de manera positiva por la temperatura. La tasa de producción de huevos aumenta exponencialmente con un aumento de la temperatura (Vidal 1980, Uye y Shibuno 1992). Además, la alta abundancia de copepoditos de E. acutifrons encontrado en nuestro estudio durante el verano indica la reproducción activa en esta temporada del año, en coincidencia con Viñas y Gaudy (1996) quienes observaron organismos maduros en el periodo de mayor temperatura en el golfo de San Matías (también en el norte de la Patagonia). A bajas temperaturas, los adultos de esta especie se mantienen en un estado de quiescencia (D'Apolito y Stancyk 1979, Viñas y Gaudy 1996), lo que explicaría las abundancias bajas durante el invierno. Esto muestra que incluso una pequeña variación en la temperatura puede afectar considerablemente la dinámica de las poblaciones de E. acutifrons. Por otro lado, las tallas más grandes de $A$. tonsa se encontraron cuando la temperatura del mar fue más baja. Esto es consistente con las observaciones de otros estudios en los que la longitud del prosoma se correlacionó negativamente con la temperatura (Chinnery y Williams 2004, Hansen et al. 2010).

Por último, en nuestro estudio se encontró una alta diversidad de especies en invierno, cuando la RUV fue baja. La RUV tiene efectos negativos sobre el fitoplancton ya que puede alterar la cantidad y calidad del alimento, lo que a su vez puede reducir la supervivencia, el crecimiento y la reproducción de zooplancton (Hessen et al. 1997). Recientemente, se ha descubierto que las tasas de mortalidad de zooplancton en el mar rojo se incrementaron en gran medida bajo la RUV, pero disminuyeron cuando la RUV se eliminó (Al-Aidaroos et al. 2015). En el área de estudio se realizaron investigaciones previas sobre los efectos de la RUV pero sólo en larvas de cangrejo (Hernández-Moresino et al. 2011, 2014; Gonçalves et al. 2014). Nuestro trabajo es el primer estudio que considera la comunidad de zooplancton, especialmente de los copépodos, y sus variaciones naturales con los factores ambientales. Esto pone de relieve la importancia potencial de los efectos de la radiación solar en el zooplancton marino de esta zona, y la necesidad de llevar a cabo estudios a largo plazo tomando en cuenta las comunidades naturales y las variaciones estacionales de la radiación solar. Por lo tanto, la baja diversidad encontrada en verano podría deberse a los efectos específicos de la radiación solar sobre las especies. En particular, nuestros resultados son los primeros sobre un ciclo anual del zooplancton en esta área productiva, y nuestras observaciones sobre la variación de las especies de copépodos en esta estación costera de la Patagonia norte sugieren diferentes estrategias de vida para esta zona. Evidentemente, se requieren más estudios con una mejor 
Di Mauro R, Capitanio F, Viñas MD. 2009. Capture efficiency for small dominant mesozooplankters (Copepoda, Appendicularia) off Buenos Aires Province $\left(34^{\circ} \mathrm{S}, 41^{\circ} \mathrm{S}\right)$, Argentine Sea, using two plankton mesh sizes. Braz. J. Oceanogr. 57: 205-14.

Di Rienzo JA, Casanoves F, Balzarini MG, Gonzalez L, Tablada M, Robledo CW. 2013. InfoStat versión 2013. Grupo InfoStat, FCA, Universidad Nacional de Córdoba, Argentina [cited August 2013]. Available from: http://www.infostat.com.ar.

Drinkwater KF, Beaugrand C, Kaeriyama M, Kim S, Ottersen G, Perry RL, Potner HO, Polovina JJ, Takasuka A. 2010. On the processes linking climate to ecosystem changes. J. Mar. Syst. 79: 374-388.

Eloire D, Somerfield PJ, Conway DVP, Halsband-Lenk C, Harris R, Bonnet D. 2010. Temporal variability and community composition of zooplankton at Station L4 in the Western Channel: 20 years of sampling. J. Plankton Res. 32: 657-679.

Eskinazi-Sant'Anna EM, Björnberg TKS. 2006. Seasonal dynamics of mesozooplankton in Brazilian coastal waters. Hydrobiologia 563: 253-268.

Gislason A, Gaard E, Debes H, Falkenhaug T. 2008. Abundance, feeding and reproduction of Calanus finmarchicus in the Irminger Sea on the northern Mid-Atlantic Ridge in June. DeepSea Res. (II) 55: 72-82.

Gonçalves RJ, Hernández-Moresino RD, Spinelli ML. 2014. Shortterm effect of UVR on vertical distribution of Cyrtograpsus altimanus and Alexandrium tamarense from Atlantic Patagonia. Lat. Am. J. Aquat. Res. 42: 963-997.

Gonçalves RJ, Hylander S. 2014. Marine copepods and solar radiation. In: Seuront L (ed.), Copepods: Diversity, Habitat and Behavior. Nova Science Publishers, pp. 101-120.

Gonçalves RJ, Souza S, Aigo J, Modenutti B, Balseiro E, Villafañe VE, Cussac V, Helbling EW. 2010. Responses of plankton and fish from temperate zones to UVR and temperature in a context of global change. Ecol. Austral 20: 129-153.

Grigor JJ, Søreide JE, Varpe Ø. 2014. Seasonal ecology and lifehistory strategy of the high-latitude predatory zooplankter Parasagitta elegans. Mar. Ecol. Prog. Ser. 499: 77-88.

Guisande C, Riveiro I, Maneiro I. 2000. Comparisons among the amino acid composition of the females, eggs and food to determine the relative importance of food quantity and food quality to copepod reproduction. Mar. Ecol. Prog. Ser. 202: 135-142.

Halac SR, Villafañe VE, Gonçalves RJ, Helbling EW. 2011. Longterm UVR effects upon phytoplankton natural communities of Patagonian coastal waters. In: Atazadeh I (ed.), Remote Sensing of Biomass: Principles and Applications. Intech Open Access Publishers, pp. 229-248.

Hansen BW, Drillet G, Kozmer A, Madsen KV, Pedersen MF, Sørensen TF. 2010. Temperature effects on copepod egg hatching: Does acclimatization matter? J. Plankton Res. 32: 305-315.

Hansen JE, Martos P, Madirolas A. 2001. Relationship between spatial distribution of the Patagonian stock of Argentine anchovy, Engraulis anchoita, and sea temperatures during late spring to early summer. Fish. Oceanogr. 10: 193-206.

Helbling EW, Santamarina JM, Villafañe VE. 1992. Chubut River estuary (Argentina): Estuarine variability under different conditions of river discharge. Rev. Biol. Mar. Oceanogr. 27: 73-90.

Helbling EW, Barbieri ES, Marcoval MA, Gonçalves RJ, Villafañe VE. 2005. Impact of solar ultraviolet radiation on marine phytoplankton from Patagonia. Photochem. Photobiol. Sci. 81: 807-818.

Helbling EW, Pérez DE, Medina CD, Lagunas MG, Villafañe VE. 2010. Phytoplankton distribution and photosynthesis dynamics resolución temporal para obtener una comprensión más profunda sobre la variabilidad interanual de esta comunidad, lo que a su vez ayudará a interpretar los efectos del cambio climático global particularmente relevantes en ambientes de altas latitudes.

\section{Agradecimientos}

MLS recibió una beca de doctorado del Consejo Nacional de Investigaciones Científicas y Técnicas (CONICET, Argentina) y este artículo fue sometido como requisito parcial para su titulación doctoral. Este trabajo fue financiado por UBACYT 20020100200048 y CONICET PIP 112201 10100351. Macarena Valiñas y Sebastian Strauch ayudaron durante el muestreo. Agradecemos a Walter Helbling el asesoramiento y apoyo, también a Sergio Fernández (Estación Marítima), quien nos proporcionó la logística en el momento del muestreo. También se agradece a la Cooperativa Eléctrica y de Servicios de Rawson por proporcionar la infraestructura del edificio. Este trabajo es la contribución 157 de la Estación de Fotobiología Playa Unión.

in the Chubut River estuary (Patagonia, Argentina) throughout tidal cycles. Limnol. Oceanogr. 55: 55-65.

Hernández-Moresino RD, Gonçalves RJ, Helbling EW. 2011. Effects for UVR on sensitivity and motility in different stages of crab larvae from coastal Patagonia (Argentina). J. Exp. Mar. Biol. Ecol. 407: 363-369.

Hernández-Moresino RD, Gonçalves RJ, Helbling EW. 2014. Direct and indirect acquisition of photoprotective compounds in crab larvae of coastal Patagonia (Argentina). J. Plankton Res. 36: $877-882$.

Hessen DO, de Lange HJ, van Donk E. 1997. UV-induced changes in phytoplankton cells and its effects on grazers. Freshwat. Biol. 38: 513-524.

Hirst AG, Bunker AJ. 2003. Growth of marine planktonic copepods: Global rates and patterns in relation to chlorophyll a, temperature, and body weight. Limnol. Oceanogr. 48: $1988-2010$

Holm-Hansen O, Riemann B. 1978. Chlorophyll $a$ determination: Improvements in methodology. Oikos 30: 438-447.

Hopcroft RR, Roff JC, Chavez FP. 2001. Size paradigms in copepod communities: A re-examination. Hydrobiologia 453: 133-141.

Kiørboe T, Nielsen TG. 1994. Regulation of zooplankton biomass and production in a temperate, coastal ecosystem. Limnol. Oceanogr. 39: 493-507.

Loots C, Swadling KM, Koubbi P. 2009. Annual cycle of distribution of three ice-associated copepods along the coast near Dumont d'Urville, Terre Adelie (Antarctica). J. Mar. Syst. 78: 599-605.

Lopes RM, Brandini FP, Gaeta SA. 1999. Distribution patterns of epipelagic copepods off Rio de Janeiro (SE Brazil) in summer 1991/1992 and winter 1992. Hydrobiologia 411: 161-174.

Mackas DL, Beaugrand G. 2010. Comparison of zooplankton time series. Mar. Syst. 79: 286-304.

Madsen SD, Nielsen TG, Hansen BW. 2001. Annual population development and production by Calanus finmarchicus, $C$. glacialis and C. hyperboreus in Disko Bay, western Greenland. Mar. Biol. 139: 75-93. 
Margalef R. 1958. Information theory in ecology. Int. J. Gen. Syst. 3: 36-71.

Mianzán HW, Guerrero RA. 2000. Environmental patterns and biomass distributions of gelatinous macrozooplankton. Three study cases in the Southwestern Atlantic Ocean. Sci. Mar. 64: 215-224.

Overland JE, Alheit J, Bakun A, Hurrell JW, Mackas DL, Miller AJ, 2010. Climate controls on marine ecosystems and fish populations. Mar. Syst. 79: 305-315.

Pájaro M, Macchi GJ, Martos P. 2004. Reproductive pattern of the Patagonian stock of Argentine hake (Merluccius hubbsi). Fish. Res. 72: 97-108.

Perry RI, Cury P, Branker K, Jennings, S, Möllmann C, Planque B, 2010. Sensitivity of marine systems to climate and fishing: Concepts, issues and management responses. J. Mar. Syst. 79: 427-435.

Pielou EC. 1969. An Introduction to Mathematical Ecology. WileyInterscience, John Wiley, New York, pp. 385.

Pittois SG, Shaw M, Fox CJ, Frid CL. 2009. A new fine-mesh zooplankton time series from the Dove sampling station (North Sea). J. Plankton Res. 31: 337-343.

Sabatini M, Martos P. 2002. Mesozooplankton features in a frontal area off northern Patagonia (Argentina). Sci. Mar. 66: 215-232.

Sautour B, Castel J. 1995. Comparative spring distribution of zooplankton in three macrotidal European estuaries. Hydrobiologia 311: 139-151.

Shannon CE, Weaver W. 1949. The Mathematical Theory of Communication. Univ. Illinois Press, Urbana, USA.

Spinelli ML, Pájaro M, Martos P, Esnal GB, Sabatini M, Capitanio FL. 2012. Potential zooplankton preys (Copepoda and Appendicularia) for Engraulis anchoita in relation to early larval and spawning distributions in the Patagonian frontal system (SW Atlantic Ocean). Sci. Mar.76: 39-47.

Turner JT. 2004. The importance of small planktonic copepods and their roles in pelagic marine food webs. Zool. Stu. 43: 255-266.

Uye S, Shibuno N. 1992. Reproductive biology of the planktonic copepod Paracalanus sp. in the Inland Sea of Japan. J. Plankton Res. 14: 343-358.

Utermöhl H. 1958. Zur Vervollkommnung der quantitativen Phytoplankton Methodik. Mitt. Int. Ver. Theor. Angew. Limnol. 9: $1-38$.
Vargas CA, González HE. 2004. Plankton community structure and carbon cycling in a coastal upwelling system. I. Bacteria, microprotozoans and phytoplankton in the diet of copepods and appendicularians. Aquat. Microbiol. Ecol. 34: 151-164.

Vidal J. 1980. Physioecology of zooplankton. I. Effects of phytoplankton concentration, temperature, and body size on the growth rate of Calanus pacificus and Pseudocalanus sp. Mar. Biol. 56: 111-134.

Villafañe VE, Banaszak AT, Guendulain-García SD, Strauch SM, Halac SR, Helbling EW. 2013. Influence of seasonal variables associated with climate change on photochemical diurnal cycles of marine phytoplankton from Patagonia (Argentina). Limnol. Oceanogr. 58: 203-214.

Villafañe VE, Barbieri ES, Helbling EW. 2004. Annual patterns of ultraviolet radiation effects on temperate marine phytoplankton off Patagonia, Argentina. J. Plankton Res. 26: 167-174.

Villafañe VE, Janknegt PJ, Graaff M, Visser RJW, van de Poll WH, Buma AGJ, Helbling EW. 2008. UVR-induced photoinhibition of summer marine phytoplankton communities from Patagonia. Mar. Biol. 154: 1021-1029.

Viñas MD, Gaudy R. 1996. Annual cycle of Euterpina acutifrons (Copepoda: Harpacticoida) in the Gulf of San Matías (Argentina) and in the Gulf of Marseilles (France). Sci. Mar. 60: 307-318

Viñas MD, Negri RM, Cepeda GD, Hernández D, Silva R, Daponte MC, Capitanio FL. 2013. Seasonal succession of zooplankton in coastal waters of the Argentine Sea (Southwest Atlantic Ocean): Prevalence of classical or microbial food webs. Mar. Biol. Res. 9: 371-382.

Williamson CE, Olson GE, Walker ND, Engstro DR, Hargreaves BR. 2001. Ultraviolet radiation and zooplankton community structure following deglaciation in Glacier Bay, Alaska. Ecology 82: 1748-1760.

Zagarese HE, Williamson CE. 1994. Modeling the impacts of UV-B radiation on ecological interactions in freshwater and marine ecosystems. In: Biggs RH, Joyner MEB (eds.), Stratospheric Ozone Depletion/UV-B Radiation in the Biosphere. SpringerVerlag, Berlin, pp. 315-328.

Received September 2015, accepted February 2016. 